\begin{tabular}{|c|c|c|c|c|}
\hline \multirow{3}{*}{$\begin{array}{l}\text { 2. ECN Category } \\
\text { (mark one) } \\
\text { Supplemental } \\
\text { Direct Revision } \\
\text { Change ECN } \\
\text { Temporary } \\
\text { Standby } \\
\text { Supersedure } \\
\text { Cancel/Noid }\end{array}$} & \multicolumn{2}{|c|}{$\begin{array}{l}\text { 3. Or iginator's Name, Organization, MSIN, } \\
\text { and Telephone No. } \\
\text { D. E. BaT1, Process } \\
\text { Engineering, R3-86, 373-0615 }\end{array}$} & $\begin{array}{l}\text { 4. USQ Required? } \\
\text { [] Yes }[\mathrm{X}] \text { No }\end{array}$ & $\begin{array}{l}\text { 5. Date } \\
\text { October 13, } 1998\end{array}$ \\
\hline & \multicolumn{2}{|c|}{$\begin{array}{l}\text { 6. Project Title/No./Work Order No. } \\
\text { Spent Nuclear Fuel }\end{array}$} & $\begin{array}{c}\text { 7. Bldg./Sys./Fac. No. } \\
\text { N/A }\end{array}$ & \\
\hline & \multicolumn{2}{|c|}{$\begin{array}{l}\text { 9. Document Numbers Changed by this ECN } \\
\text { (includes sheet no. and rev.) } \\
\text { HNF-1523, Rev } 0\end{array}$} & $\begin{array}{l}\text { 10. Related ECN No(s). } \\
\text { N/A }\end{array}$ & 11. Related PO No. \\
\hline \multirow{2}{*}{$\begin{array}{l}\text { 12a. Modification Work } \\
\text { [] Yes (fill out Blk. } \\
\text { [X] No (NA Biks, 12b, } \\
12 c, 12 d)\end{array}$} & \multirow[t]{2}{*}{$\begin{array}{l}\text { 12b. Work Package } \\
\text { No. } \\
\text { N } / A\end{array}$} & \multirow{2}{*}{$\begin{array}{l}\text { 12c. Modification Work Complete } \\
\text { N/A } \\
\begin{array}{c}\text { Design Authority/Cog. Engineer } \\
\text { Signature \& Date }\end{array}\end{array}$} & \multicolumn{2}{|c|}{$\begin{array}{l}\text { 12d. Restored to Originat Condi- } \\
\text { tion (Temp. or Standby ECN only) } \\
\mathbb{N} / \mathrm{A}\end{array}$} \\
\hline & & & $\begin{array}{l}\text { Engineer } \\
\text { te }\end{array}$ & $\begin{array}{l}\text { Design Authority/Cog. Engineer } \\
\text { Signature \& Date }\end{array}$ \\
\hline \multicolumn{5}{|c|}{$\begin{array}{l}\text { 13a. Description of change } \\
\text { Complete document revision. The analysis, FAI/97-9 } \\
\text { has been replaced by FAI/98-97 Rev } 3 \text {. This new ana } \\
\text { inventory estimates based on revised MCO particulat } \\
\text { follow-on calculations of MCO pressure and gas comp } \\
\text { pressure and gas composition can now be found in HN }\end{array}$} \\
\hline
\end{tabular}

14a. Justification (mark one)

Criteria Change [X] Design Improvement [] Environmental [] Facility Deactivation

As-Found [] Facilitate Const [] Const. Error/Omission [] Design Error/Omission
pressure responses in two documents was eliminated.

15. Distribution (include name, MSIN, and no. of copies)

See Page 2 of this ECN for Approval signatures. See attached Distribution sheet for distribution.

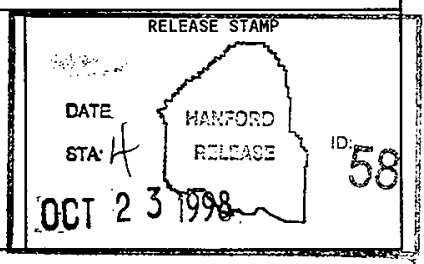

A-7900-013-2 (05/96) GEF095 


\begin{tabular}{|l|llllll|}
\hline 16. Design & \multicolumn{3}{|c}{ 17. Cost Impact } \\
Verification & \multicolumn{3}{|c}{ ENGINEER ING } & \multicolumn{3}{c|}{ CONSTRUCTION } \\
$\begin{array}{l}\text { Required } \\
{[] \text { Yes }}\end{array}$ & Additional & {[]} & $\$$ & Additional & [] & $\$$ \\
{$[X]$ No } & Savings & {[]} & $\$$ & Savings & {[]} & $\$$
\end{tabular}
648613

19. Change Impact Revieu: Indicate the related documents (other than the engineering documents identified on Side 1 ) that will be affected by the change described in Block 13 . Enter the affected document number in Block 20.

\section{SDD/DD}

Functional Design Criteria

Operating Specification

Criticality Specification

Conceptuat Design Report

Equipment Spec.

Const. Spec.

Procurement Spec.

Vendor Information

OM Manual

FSAR/SAR

Safety Equipment List

Radiation Work Permit

Environmental Impact Statement.

Environmental Report

Environmental Permit
[]

[]

[]

[]

[]

[]

[]

[]

[]

[]

[x]

[]

[]

[]

[]

[]
Seismic/Stress Analysis

Stress/Design Report

Interface Control Drawing

Calibration Procedure

Installation Procedure

Maintenance Procedure

Engineering Procedure

Operating Instruction

Operating Procedure

Operational Safoty Requirement

IEFD Drawing

Cell Arrangement Drawing

Essential Material Specification

Fac. Proc. Samp. Schedulo

Inspection Plan

Inventory Adjustment Request
[]

[]

[]

[]

[]

[]

[]

[]

[]

[]

[]

[]

[]

[]

[]
18. Schedute Impact (days)

Improvement []

[]

20. Other Affected Documents: (NOTE: Documents listed below will not be revised by this ECN.) signatures below indicate that the signing organization has been notified of other affected documents listed below. Document Number/Revision

HNF-SD-SNF-TI-015, rev 5

\section{Approvals}

Design Authority

Date

signature

Date

Cog. Eng. D. R. Duncan (lRhlunaem

Cog. Mgr. d. R. Frederickson funderuth

QA D. W. smith DASDDith

safety R. P. omberg $P \& C$ mang

Environ.

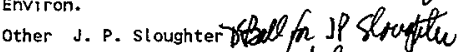
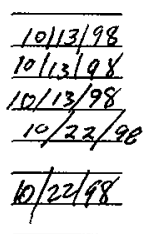

Design Agent

PE

QA

Safety

Design

Environ.

other

DEPARTMENT OF ENERGY

signature or a Control Number that

tracks the Approval signature

ADDITIONAL

1
1
1
1
1
1
1
1
1
1
1
1




\title{
K-Basins Particulate Water Content, and Behavior
}

\author{
D. R. Duncan, *M. G. Plys
}

DE\&S Hanford, Richland, WA 99352

U.S. Department of Energy Contract DE-AC06-96RL13200

EDT/ECN: 648613

Org Code: 2F300

B\&R Code: EW3135040
UC: 510

Charge Code: 105355, BA40

Total Pages: 104

Key Words: N-Reactor fuel, CVD process, particulate water content, characterization

Abstract: This analysis summarizes the state of knowledge of $\mathrm{K}$-basins spent nuclear fuel oxide (film, particulate or sludge) and its chemically bound water in order to estimate the associated multicanister overpack (MCO) water inventory and to describe particulate dehydration behavior. This information can be used to evaluate the thermal and chemical history of an MCO and its contents during cold vacuum drying (CVD), shipping, and interim storage.

* Fauske \& Associates

TRADEMARK DISCLAIMER. Reference herein to any specific comercjal product, process, or service by trade name, trademark, manufacturer, or otherwise, does not necessarily constitute or imply its endorsement, recommendation, or favoring by the United States Government or any agency thereof or its contractors or subcontractors.

Printed in the United States of America. To obtain copies of this document, contact: Document Control Services, P.0. Box 950, Mailstop H6-08, Richland WA 99352, Phone (509) 372-2420;

Fax (509) $376-4989$.
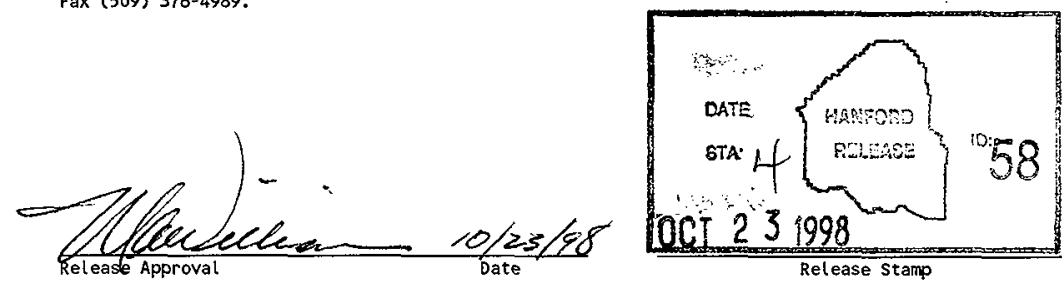

\section{Approved for Public Release}


(2) Title

K-Basins Particulate Water Content, Behavior, and Impact

CHANGE CONTROL RECORD

\begin{tabular}{|c|c|c|c|c|}
\hline & \multirow{2}{*}{ Revision } & \multirow{2}{*}{ (4) Description of Change - Replace, Add, and Delete Pages } & \multicolumn{2}{|c|}{ Authorized for Release } \\
\hline & & & (5) Cog. Engr. & (6) Cog. Mgr. \\
\hline & 0 & (7) Re7eased by EDT \#616191, 11/19/97 & $\begin{array}{l}\text { D. R. } \\
\text { Duncan }\end{array}$ & $\begin{array}{l}\text { J. R. } \\
\text { Frederickson }\end{array}$ \\
\hline RS & 1 & $\begin{array}{l}\text { Complete document revision. The analysis, } \\
\text { FAI/97-90 Rev. 4, attached to HNF-1523, } \\
\text { Rev. 0 has been replaced by FAI/98-97 Rev. } \\
3 \text {. This new analysis provides updated MCO } \\
\text { water inventory estimates based on revised } \\
\text { MCO particulate inventory estimates and } \\
\text { eliminates follow-on calculations of MCO } \\
\text { pressure and gas composition. The } \\
\text { calculations of MCO pressure and gas } \\
\text { composition can now be found in HNF-SD-TI- } \\
040 \text {. }\end{array}$ & $\begin{array}{l}\text { D. R. ORluace } \\
\text { Duncan } 10 / 23 / 48\end{array}$ & $\begin{array}{l}\text { W. R. QRAkidenian } \\
\text { Frederickson'o/23/s }\end{array}$ \\
\hline & & & & \\
\hline & & & & \\
\hline & & & & \\
\hline & & & & \\
\hline & & & & \\
\hline & & & & \\
\hline & & & & \\
\hline & & & & \\
\hline & & & & \\
\hline & & & & \\
\hline & & & & \\
\hline & & & & \\
\hline & & & & \\
\hline & & & & \\
\hline & & & & \\
\hline
\end{tabular}


HNF-1523, Rev 1

FAI/98-97, Rev. 3

K-BASINS PARTICULATE WATER CONTENT, BEHAVIOR, AND IMPACT

\author{
Submitted To: \\ Duke Engineering \& Services Hanford, Inc. \\ 2355 Stevens Drive \\ Richland, WA 99352
}

Prepared By:

Martin G. Plys

Fauske \& Associates, Inc.

16W070 West 83rd Street

Burr Ridge, Illinois. 60521

Tel: (630) 323-8750 ax: (630) 986-5481

October 1998 


\section{TABLE OF CONTENTS}

Page

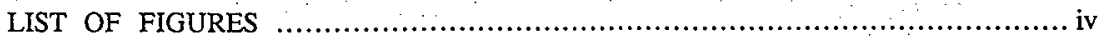

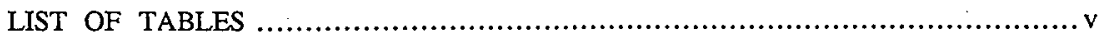

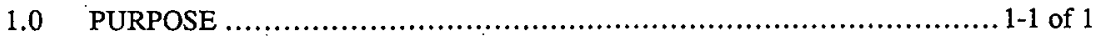

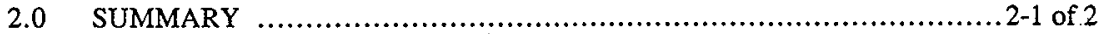

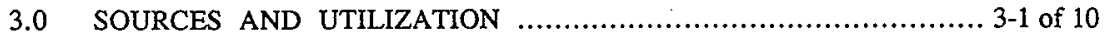

3.1 MCO Particulate Inventory ..................................................

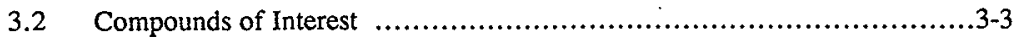

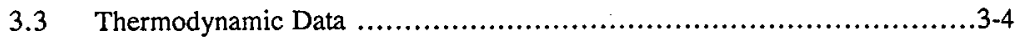

3.4 Aluminum Hydroxide Films ..........................................

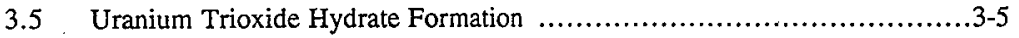

3.6 Uranium Trioxide Hydrate Decomposition ................................... 3-6

3.7 Uranium Peroxide Hydrate Formation ...................................... 3-7

3.8 Uranium Peroxide Hydrate Decomposition ..................................

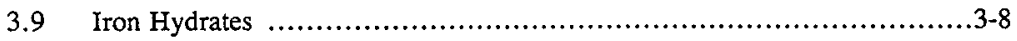

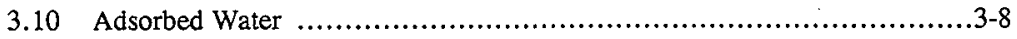

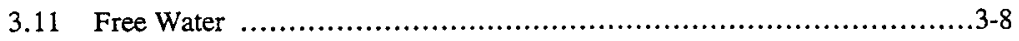

3.12 K-Basins Canister Particulate Physical Property Data ........................3-8

3.13 K-East Canister Particulate Dryout Data ................................. 3-10

4.0 TECHNICAL BASES AND ASSUMPTIONS ............................ 4-1 of 3

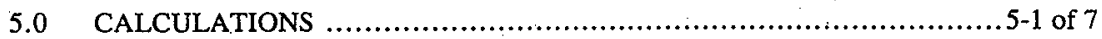

5.1 Cladding Surface Films .....................................................

5.2 Oxide Films on Scrap and Fuel ............................................. 5-1

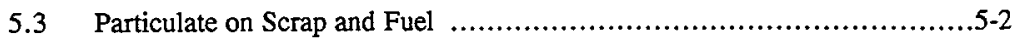

5.4 Canister Particulate .........................................................

5.5 Generated Particulate ........................................................5-4

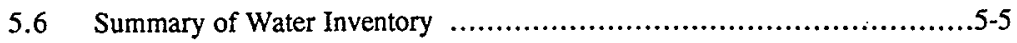

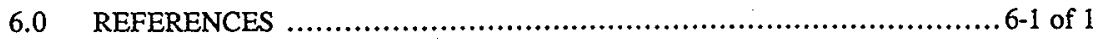




\section{TABLE OF CONTENTS \\ (concluded)}

APPENDIX A APPENDIX B APPENDIX $\mathrm{C}$ APPENDIX D APPENDIX E APPENDIX $\mathrm{F}$ APPENDIX G APPENDIX H APPENDIX I

APPENDIX J

APPENDIX $\mathrm{K}$ APPENDIX L
Thermodynamic Data and Implications A-1 of 6 Thermo-Gravimetric Analysis of $\mathrm{Al}(\mathrm{OH})_{3}$ Coating B-1 of 3 Uranium Trioxide Hydrate Formation C-1 of 4 Uranium Trioxide Hydrate Decomposition D-1 of 5 DELETED E-1 of 1 Interpretation of PNNL Dryout Experiments F-1 of 6 Uranium Peroxide Hydrate Formation and Decomposition G-1 of 7 Adsorbed Water on Oxide Surfaces H-1 of 3 K-Basins Sludge Physical Property Data Draft Reference Excerpts I-1 of 5 DELETED $\mathrm{J}-1$ of 1 DELETED $\mathrm{K}-1$ of 1 Calculation Note Cover Sheet and Methodology Checklist L-1 of 3 


\section{LIST OF FIGURES}

Figure

$\underline{\text { Page }}$

3-1 Weight Loss Over the Temperature Ranges $100^{\circ} \mathrm{C}$ to $300^{\circ} \mathrm{C}$ Versus Percent Aluminum and Iron Hydroxides in Canister Particulate Samples from K-East and $\mathrm{K}$-West Basin Canisters

A-1 Equilibrium Decomposition Curves for the $\mathrm{UO}_{3} \times \mathrm{xH}_{2} \mathrm{O}$ Family A-4

B-1 Thermo-Gravimetric Analysis Drying Results from Coating Sample CS-4

B-2 Duplicate Thermo-Gravimetric Analysis Drying Data from Coating Sample CS-4

C-1 Danroc's $\mathrm{UO}_{3} \cdot 2 \mathrm{H}_{2} \mathrm{O}$ Formation Data: Aging of Submicron $\mathrm{UO}_{2}$ Powder in Humid Air

D-1 French $\mathrm{UO}_{3} \times \mathrm{H}_{2} \mathrm{O}$ Decomposition Data D-3

F-1 Figure F-1 F-3

F-2 Figure F-2 F-4

F-3 Figure F-3 F-5

F-4 Figure F-4 F-6

G-1 Variation of Mol. Ratio $\mathrm{H}_{2} \mathrm{O} / \mathrm{UO}_{4}$ in $\mathrm{UO}_{4} \cdot 4 \mathrm{H}_{2} \mathrm{O}$ (specimen 1) With Time Of Drying in Vacuum at Room Temperature G-2

G-2 Thermal Decomposition of $\mathrm{UO}_{4} \cdot \mathrm{xH}_{2} \mathrm{O}$ G-4

G-3 Draft, Unqualified PNNL Drying Curve for Surface Coating Believed Composed of $\mathrm{UO}_{4} \cdot 4 \mathrm{H}_{2} \mathrm{O}$ G-6

I-1 K-East Sludge Observed Physical Properties $\mathrm{I}-2$ 


\section{LIST OF TABLES}

Table

Page

3-1 Summary of Derived Particulate Mass Values

3-2 K-East Canister Particulate Hydrate Water Content Based on [Abrefah, et al., 1998] 3-10

5-1 Summary of Water Content Values ...........................................

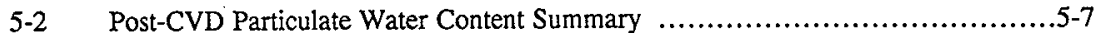

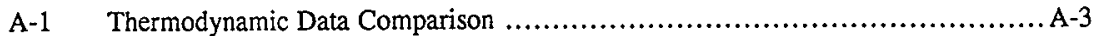

F-1 Decomposition Parameters of KE Canister Sludge .......................... F-2

F-2 Best-Fit Arrhenius Parameters for Decomposition $\ldots \ldots \ldots \ldots \ldots \ldots \ldots \ldots \ldots \ldots \ldots \ldots$ F-2 


\subsection{PURPOSE}

The purpose of this work is to summarize the state of knowledge of $\mathrm{K}$-basins spent nuclear fuel oxide (also called particulate or sludge) and its chemically bound water in order to estimate the associated multi-canister overpack (MCO) water inventory and to describe particulate dehydration behavior. This information can be used to evaluate the thermal and chemical history of an $\mathrm{MCO}$ and its contents during cold vacuum drying (CVD), shipping, and interim storage.

Low, nominal, and high $\mathrm{MCO}$ bound water content values after CVD are provided. A best-estimate law for uranium oxide hydrate thermal decomposition behavior is provided for prediction of water supply rate from this source during and after CVD.

This revision provides new MCO water inventory estimates based on revised $\mathrm{MCO}$ particulate inventory estimates [Sloughter, 1998], and eliminates follow-on calculations of MCO pressure and gas composition which are performed in more detail elsewhere [Plys, 1998]. Previous revisions (FAI/97-90, Rev. 4 and FAl/98-97, Rev. 1 and Rev. 2) contained a variety of information and calculations that were first-of-a-kind estimates or based on draft data, so some sections are omitted or revised using new information. 


\subsection{SUMMARY}

Recent estimates of MCO particulate content (fuel oxide and hydrated fuel oxides) and recent experimental data on $\mathrm{K}$-basins particulate dryout rates and physical properties are used here to estimate the range of expected MCO water content. Kinetic data for dehydration are refined for thermal modeling, but thermal decomposition is not credited here. MCO particulate content estimates, a source for this document, are largest for the case of an MCO with two scrap and three fuel baskets. For this case estimated values are $30 \mathrm{~kg}$ high, $6 \mathrm{~kg}$ nominal, and $1 \mathrm{~kg}$ low loaded at the K-basins [Sloughter, 1998] and excluding corrosion product generated after fuel cleaning.

Water inventory estimates, including generated particulate and free water sources, are $(\mathrm{kg})$ :

\begin{tabular}{|l|c|c|c|}
\hline \multicolumn{1}{|c|}{ Scrap Baskets } & High & Nominal & Low \\
\hline Zero Scrap Baskets & 4.52 & 1.30 & 0.26 \\
One Scràp Basket & 4.67 & 1.25 & 0.26 \\
Two Scrap Baskets & 4.84 & 1.21 & 0.26 \\
\hline
\end{tabular}

The high water inventory is nearly independent of the number of scrap baskets because the $\mathrm{Al}(\mathrm{OH})_{3}$ content is nearly constant. The nominal water inventory is about $1.25 \mathrm{~kg}$ and the low water content is about $1 / 4 \mathrm{~kg}$ in all cases. See Tables 5-1 and 5-2 for details.

The most significant contributor to the high $\mathrm{MCO}$ water estimate is an $\mathrm{Al}(\mathrm{OH})_{3}$ film on cladding, whose water content lies between 3.3 and $3.7 \mathrm{~kg}$. This film may not thermally decompose during either CVD, transport, or interim storage, so its water would only contribute to $\mathrm{MCO}$ pressurization by radiolysis. The next most significant high estimate contributors are adhering particulate for the case of two scrap baskets, about $1 \mathrm{~kg}$ water, and adhering particulate and canister particulate for the case of zero scrap baskets, about 0.3 and $0.24 \mathrm{~kg}$ water, respectively. But $92 \%$ of the high estimate canister particulate water is from $\mathrm{Al}$ and $\mathrm{Fe}$ hydrates that may not thermally decompose. Thus the case with the highest water inventory subject to 
thermal decomposition is for two scrap baskets, where about $1.2 \mathrm{~kg}$ water from uranium oxide hydrates is the high value. Water borne by particulate generated after MCO loading is less than half of the 200 grams free water that may remain after CVD. 


\subsection{SOURCES AND UTILIZATION}

Reference sources used to create technical bases and formulate assumptions are summarized here; detailed review of references is relegated to appendices where indicated. The meaning of reference data and their purpose for utilization are also discussed.

Sources are mentioned as follows: Section 3.1, MCO particulate inventory estimates which will be used to estimate the MCO water inventory; Section 3.2, a summary of waterbearing compounds of interest to MCO pressurization; Sections 3.3 to 3.11, details of these compounds; and Section 3.12, physical property data for particulate which are useful in understanding particulate composition.

\subsection{MCO Particulate Inventory}

Estimates of MCO particulate inventory are provided by [Sloughter, 1998]. The scope of the inventory includes material loaded into an $\mathrm{MCO}$ at $\mathrm{K}$-basins that is literally not cladding and fuel in their original form. The term 'Particulate' is used because corrosion products become small, potentially entrainable particles. 'Sludge' is another term for existing K-basins corrosion products without specific regard to source, and this term is used in a variety of references sited herein. 'Canister particulate' refers to particulate found at the bottom of fuel canisters and within flow channels of a fuel assembly. The terms canister particulate and canister sludge are assumed synonymous in the report.

Table 3-1 contains the [Sloughter, 1998] inventory summary by source after fuel cleaning without further corrosion. Three estimates, high, nominal, and low, are supplied to illustrate the perceived range per particulate source. The cladding film consists of $\mathrm{Al}(\mathrm{OH})_{3}$ for elements stored in closed aluminum canisters at $\mathrm{K}$-West, visible as a thick white layer, and as a grey coating chiefly comprised of $\mathrm{UO}_{4} 4 \mathrm{H}_{2} \mathrm{O}$ otherwise. Oxide layers exist on exposed metallic 
Table 3-1: Summary of Derived Particulate Mass Values, $\mathrm{kg} / \mathrm{MCO}$

\begin{tabular}{|c|c|c|c|c|c|c|c|c|c|}
\hline \multirow{2}{*}{ Source } & \multicolumn{3}{|c|}{$\begin{array}{l}\text { Zero Scrap - } \\
\text { Five Fuel Baskets }\end{array}$} & \multicolumn{3}{|c|}{$\begin{array}{l}\text { One Scrap - } \\
\text { Four Fuel Baskets }\end{array}$} & \multicolumn{3}{|c|}{$\begin{array}{l}\text { Two Scrap - } \\
\text { Three Fuel Baskets }\end{array}$} \\
\hline & High & Nominal & Low & High & Nominal & Low & High & Nominal & Low \\
\hline $\begin{array}{l}\text { Aluminum Hydroxide } \\
\text { Cladding Surface Film } \\
\text { Scrap } \\
\text { Fuel } \\
\end{array}$ & $\begin{array}{c}0 \\
10.65 \\
\end{array}$ & $\begin{array}{c}0 \\
2.66 \\
\end{array}$ & $\begin{array}{l}0 \\
0 \\
\end{array}$ & $\begin{array}{l}1.54 \\
8.51 \\
\end{array}$ & $\begin{array}{l}0.39 \\
2.13 \\
\end{array}$ & $\begin{array}{l}0 \\
0 \\
\end{array}$ & $\begin{array}{l}3.08 \\
6.39 \\
\end{array}$ & $\begin{array}{l}0.77 \\
1.60 \\
\end{array}$ & $\begin{array}{l}.0 \\
0 \\
\end{array}$ \\
\hline $\begin{array}{l}\text { Uranium Peroxide } \\
\text { Cladding Surface Film } \\
\text { Scrap } \\
\text { Fuel } \\
\end{array}$ & $\begin{array}{l}0 \\
0 \\
\end{array}$ & $\begin{array}{c}0 \\
0.35 \\
\end{array}$ & $\begin{array}{c}0 \\
0.47 \\
\end{array}$ & $\begin{array}{r}0 \\
0 \\
\end{array}$ & $\begin{array}{l}0.05 \\
0.28 \\
\end{array}$ & $\begin{array}{l}0.07 \\
0.38 \\
\end{array}$ & $\begin{array}{l}0 \\
0\end{array}$ & $\begin{array}{l}0.10 \\
0.21 \\
\end{array}$ & $\begin{array}{l}0.14 \\
0.28 \\
\end{array}$ \\
\hline $\begin{array}{l}\text { Oxide Film } \\
\text { Scrap } \\
\text { Fuel }\end{array}$ & $\begin{array}{c}0 \\
0.4 \\
\end{array}$ & $\begin{array}{c}0 \\
0.006 \\
\end{array}$ & $\begin{array}{c}0 \\
0.002 \\
\end{array}$ & $\begin{array}{l}0.45 \\
0.32 \\
\end{array}$ & $\begin{array}{l}0.05 \\
0.01\end{array}$ & $\begin{array}{c}0.03 \\
0.002 \\
\end{array}$ & $\begin{array}{c}0.9 \\
0.24 \\
\end{array}$ & $\begin{array}{c}0.1 \\
0.004\end{array}$ & $\begin{array}{l}0.06 \\
0.001\end{array}$ \\
\hline $\begin{array}{l}\text { Adhering Particulate } \\
\text { Scrap } \\
\text { Fuel }\end{array}$ & $\begin{array}{c}0 \\
5.4\end{array}$ & $\begin{array}{c}0 \\
2.05 \\
\end{array}$ & $\begin{array}{c}0 \\
0.35 \\
\end{array}$ & $\begin{array}{r}7.80 \\
4.32 \\
\end{array}$ & $\begin{array}{l}0.78 \\
1.64 \\
\end{array}$ & $\begin{array}{l}0.23 \\
0.28 \\
\end{array}$ & $\begin{array}{l}15.60 \\
3.24\end{array}$ & $\begin{array}{l}1.56 \\
1.23 \\
\end{array}$ & $\begin{array}{l}0.47 \\
0.21 \\
\end{array}$ \\
\hline Canister Particulate & $1: 6$ & 0.65 & 0 & 1.28 & 0.52 & 0 & 0.96 & 0.39 & 0 \\
\hline $\begin{array}{l}\text { TOTAL } \\
\text { Rounded TOTAL }\end{array}$ & $\begin{array}{c}18.05 \\
18\end{array}$ & $\begin{array}{c}5.72 \\
6\end{array}$ & $\begin{array}{c}0.82 \\
1\end{array}$ & $\begin{array}{l}24.22 \\
24\end{array}$ & $\begin{array}{c}5.85 \\
6\end{array}$ & $\begin{array}{c}0.99 \\
1\end{array}$ & $\begin{array}{c}30.41 \\
30\end{array}$ & $\begin{array}{c}5.96 \\
6\end{array}$ & $\begin{array}{c}1.16 \\
1\end{array}$ \\
\hline
\end{tabular}


surfaces. Adhering Particulate listed in Table 3-1 consists of adhering and trapped particles found at fuel damage sites.

Particulate is generated after fuel cleaning due to corrosion in the basin, transfer to CVD, and at CVD before drainage and during the drying process itself. [Sloughter, 1998] provides a summary of post-cleaning particulate generation for a bounding MCO with two scrap baskets and a nominal MCO with one scrap basket. For a bounding $\mathrm{MCO}, 15 \mathrm{~kg}$ are estimated to be generated up to the time of MCO drainage, and $9.8 \mathrm{~kg}$ are estimated to be formed during CVD. For a nominal MCO, corresponding values are $0.075 \mathrm{~kg}$ and $0.309 \mathrm{~kg}$.

Descriptions of the fuel loading process and fuel damage pertinent to the inventory are fully described in the reference and will not be repeated here.

\subsection{Compounds of Interest}

Compounds present in fuel coatings and particulate have been studied by [Sloughter and Barney, 1998]. Canister particulate TGA experiments by [Abrefah, 1998] and cladding film TGA data by [Marshman and Abrefah, 1997] provide further information. Direct observation or hypothesis yield these potential sources of water in an MCO:

$\mathrm{Al}(\mathrm{OH})_{3}$, aluminum hydroxide, is found as a white or translucent film on cladding of fuel assemblies in some K-West aluminum canisters (which are sealed); it is not found on cladding in $\mathrm{K}$-East canisters (which are open) or $\mathrm{K}$-West steel canisters [summarized in Sloughter, 1998]. Some $\mathrm{Al}(\mathrm{OH})_{3}$ may be present in particulate as well, comprising about $12 \%$ of canister particulate [Sloughter and Barney, 1998]. This compound can yield 1.5 moles $\mathrm{H}_{2} \mathrm{O}$ per mole Al, about 35 weight percent.

$\mathrm{UO}_{3} \cdot \mathrm{xH}_{2} \mathrm{O}$, uranium trioxide hydrate, where $\mathrm{x}=2$, schoepite, $\mathrm{x}=0.85$ to 1.0 , dehydrated schoepite, and possibly $x=0.5$ may either occur in uranium metal corrosion product [Danroc, 1982, and Taylor, et al., 1993] or may be formed by decomposition (see Appendix $\mathrm{C}$ references regarding the decomposition behavior 
of $\mathrm{UO}_{3}$ hydrates). $\mathrm{UO}_{2}(\mathrm{OH})_{2}$ and $\mathrm{U}_{3} \mathrm{O}_{8}(\mathrm{OH})_{2}$ exist-as compounds, but do not appear to be a priori present. Uranium oxides and hydroxides comprise the major fraction of canister particulate, about 72\% [Sloughter and Barney, 1998].

$\mathrm{UO}_{4} \times \mathrm{xH}_{2} \mathrm{O}$, uranium peroxide hydrate, has been observed with $\mathrm{x}=4$ as the primary constituent of a grey film on cladding [Marschman and Abrefah, 1997], and $x=2$ is its decomposition product [Sato, 1963].

$\mathrm{Fe}(\mathrm{OH})_{3}$, iron hydroxide, and iron oxides, $\mathrm{Fe}_{2} \mathrm{O}_{3}$, hematite, and $\mathrm{Fe}_{3} \mathrm{O}_{4}$, magnetite, have been found in canister particulate [Sloughter and Barney, 1998]. These comprise about 13 weight percent of canister particulate.

Adsorbed water can potentially exist in multiple molecular layers fixed by hydrogen bonding to uranium oxide surfaces.

Free water can potentially remain in an MCO after cold vacuum drying, despite the fact that the purpose of cold vacuum drying is to remove this water and that pressurization tests exist to detect its presence. Hypothetical sources are: (1) Water contained in reentrant surface cavities, (2) Water which locally froze to ice during drying and did not thaw sufficiently for detection, (3) Water present in internal porosity of corrosion product, (4) Water retained between cladding and fuel whose escape is prevented by fuel corrosion product completely sealing off connected porosity, and (5) Water retained in cracks in fuel whose escape is similarly prevented.

Hypothetically, other compounds that exist in the K-basins could also be included in the $\mathrm{MCO}$, such as hydrates present in concrete spallation products, constituents of resin beads which could evolve hydrocarbon gases, and biological sources which could evolve water and hydrocarbons. These are excluded from consideration based on assumptions of the particulate inventory panel [Sloughter, 1998].

References regarding these potential water sources are discussed subsequently.

\subsection{Thermodynamic Data}

Thermodynamic data for compounds of interest are summarized in Appendix A, and implications of these data are presented there as well. Thermodynamic data are used to make judgements regarding the potential for formation or decomposition of water-bearing compounds. 
The most important implication from thermodynamic data is that formation of uranium trioxide hydrates is deemed practically impossible during cold vacuum drying steps after MCO drainage because of the relative values of partial pressures of water vapor (marginal), oxygen (too: low), and hydrogen (too high). This conclusion applies to uranium peroxide hydrates too.

\subsection{Aluminum Hydroxide Films}

Films of $\mathrm{Al}(\mathrm{OH})_{3}$ observed on cladding in closed $\mathrm{K}$-West aluminum canisters have the potential to partially decompose during cold vacuum drying and interim storage based on evidence presented by [Sloughter and Barney, 1998]. In crystalline form, this compound is not expected to thermally decompose because temperatures greater than $100^{\circ} \mathrm{C}$ are required. However, amorphous $\mathrm{Al}(\mathrm{OH})_{3}$ can partially decompose in vacuum near $50^{\circ} \mathrm{C}$, although its decomposition in nitrogen occurs at about $100^{\circ} \mathrm{C}$. PNNL TGA data for two samples (see Appendix B) suggest that thermal decomposition will begin at about $100^{\circ} \mathrm{C}$, but it cannot be demonstrated that these samples represent the entire population. Thus while radiolytic decomposition probably is the only dominant physical process for evolution of water from $\mathrm{Al}(\mathrm{OH})_{3}$, thermal decomposition cannot be definitively ignored at this time.

\subsection{Uranium Trioxide Hydrate Formation}

$\mathrm{UO}_{3} \cdot 2 \mathrm{H}_{2} \mathrm{O}$ is formed under appropriate circumstances below temperatures between $80^{\circ} \mathrm{C}$ and $100^{\circ} \mathrm{C}$, while $\mathrm{UO}_{3} \cdot 0.8 \mathrm{H}_{2} \mathrm{O}$ is similarly formed at temperatures of $100^{\circ} \mathrm{C}$ and above [Danroc, 1982]. The circumstances required are simultaneous presence of nontrivial partial pressures of oxygen and water vapor, e.g., air saturated with water vapor at $60^{\circ} \mathrm{C}$ to $80^{\circ} \mathrm{C}$ or oxygen-saturated water [Danroc, 1982, and Taylor, et al., 1993]. Formation rate data presented in Appendix C show a maximum of $5 \%$ molar conversion of $\mathrm{UO}_{2}$ to $\mathrm{UO}_{3} \cdot 2 \mathrm{H}_{2} \mathrm{O}$ in 7 days at $60^{\circ} \mathrm{C}$, when the initial $\mathrm{UO}_{2}$ consists of finely divided, high specific area particles of about 0.2 micron diameter. 
From references discussed in Appendix $\mathrm{C}, \mathrm{UO}_{2}(\mathrm{OH})_{2}$ and $\mathrm{U}_{3} \mathrm{O}_{8}(\mathrm{OH})_{2}$ are not expected to be significant.

In practice, $\mathrm{UO}_{3}$ hydrates are simply not formed unless both water vapor and oxygen are present in substantial quantity, but there is no experimental quantification of a lower bound on oxygen concentration for the simple and expedient reason that conditions for formation of the hydrate in reasonable time are reported and ineffective conditions are avoided. As explained in Appendix A, conditions during CVD are at least ineffective, and probably prohibitive, for hydrate formation based on the literature. Formation rate data may be used to provide a conservative bound on water content via this mechanism.

\subsection{Uranium Trioxide Hydrate Decomposition}

$\mathrm{UO}_{3} \cdot 2 \mathrm{H}_{2} \mathrm{O}$ decomposition rates depend upon both temperature and ambient water vapor partial pressure. Decomposition to $\mathrm{UO}_{3} \cdot \mathrm{H}_{2} \mathrm{O}$ has been observed under high vacuum at room temperature [Danroc, 1982] as described in Appendix D. However, the potential for decomposition must decrease with increasing water vapor pressure. PNNL experimental data of [Abrefah, et al., 1998] can be used for rate law derivation. As discussed in Appendix F, $\mathrm{UO}_{3} \cdot 2 \mathrm{H}_{2} \mathrm{O}$ decomposition to $\mathrm{UO}_{3} \cdot \mathrm{H}_{2} \mathrm{O}$ appears to proceed with a first-order half-life of about 88 hours at the CVD temperature of $50^{\circ} \mathrm{C}$ and a steam pressure of about $100 \mathrm{mtorr}(13 \mathrm{~Pa})$. Thus much of this compound would remain in an MCO after CVD.

Loss of the remaining moles of water per mole of uranium appears to occur in two steps, first to either $\mathrm{UO}_{3} \cdot 0.8 \mathrm{H}_{2} \mathrm{O}$ [Danroc, 1982] or to $\mathrm{UO}_{3} \cdot 0.5 \mathrm{H}_{2} \mathrm{O}$ [Abrefah, et al., 1998], but the required temperatures exceed those planned for CVD. Thus these latter steps are expected to be significant only during storage at temperatures in excess of $50^{\circ} \mathrm{C}$. 


\subsection{Uranium Peroxide Hydrate Formation}

Uranium peroxide hydrate is typically formed by precipitation from uranium nitrate in $=$ : nitric acid solution treated with hydrogen peroxide, as discussed in Appendix G. Obviously this condition does not exist at the $\mathrm{K}$-basins, and a corrosion mechanism involving formation of aqueous uranium-bearing ions, their transport, and subsequent formation of insoluble compounds at or near cladding surfaces may be hypothesized to explain the observed surface cladding film. The role of radiolysis in this process is not quantified.

Since the precise mechanism for formation of the layer on cladding is unknown, the potential for formation of this compound elsewhere, such as on or inside corrosion product adhering to reactive metal or in spalled particles, is similarly unknown. Literature recipes for formation of $\mathrm{UO}_{4}$ hydrates cannot be used to explain the presence or location of these compounds on fuel in the K-basins.

\subsection{Uranium Peroxide Hydrate Decomposition}

Uranium peroxide hydrate easily decomposes from $\mathrm{UO}_{4} \cdot 4 \mathrm{H}_{2} \mathrm{O}$ to $\mathrm{UO}_{4} \cdot 2 \mathrm{H}_{2} \mathrm{O}$ at room temperature in vacuum and between $50^{\circ} \mathrm{C}$ and $75^{\circ} \mathrm{C}$ at $4 \mathrm{mtorr}$ as discussed in Appendix G. Loss of the remaining water is accompanied by reduction to $\mathrm{UO} 3$, but only at temperatures well in excess of those planned at CVD. Therefore, the ratio of moles water per mole uranium associated with this compound after CVD should be the same as that of undecomposed $\mathrm{UO}_{3} \cdot 2 \mathrm{H}_{2} \mathrm{O}$. Decomposition data for uranium peroxide hydrate is used later to assign a post-CVD water content to corrosion product initially containing this compound. 


\subsection{Iron Hydrates}

Iron hydrates discussed by [Sloughter and Barney, 1998] are not expected to decompose-: below $100^{\circ} \mathrm{C}$, so any loaded inventory would survive CVD. Figure $3-1$, reproduced from [Sloughter and Barney, 1998], illustrates the relationship between weight loss and a priori estimated $\mathrm{Fe}$ and $\mathrm{Al}$ hydroxide content in canister particulate. This information can be used to bound canister particulate water content.

\subsection{Adsorbed Water}

Adsorbed water can exist in layers of one or more molecules thick attached by hydrogen bonds to oxide surfaces. There are no data at present for adsorbed water on $\mathrm{K}$-basins fuel. As shown in Appendix $\mathrm{H}$, the quantity of adsorbed water potentially present in an $\mathrm{MCO}$ is negligible.

\subsection{Free Water}

There are no data taken with $\mathrm{K}$-basins fuel for the amount of free water that could remain in an MCO after CVD. Sensitivity of results to this water source is discussed later, and indicates a project requirement that CVD remove free water effectively.

\subsection{K-Basins Canister Particulate Physical Property Data}

K-basins canister particulate physical property data for bulk density, particle density, water content, and uranium content are summarized in Appendix I. These data are used later to make inferences of the hydrate content of particulate which clings tenaciously to exposed fuel surfaces. 
Figure 3-1:

Weight Loss Over the Temperature Ranges $100^{\circ} \mathrm{C}$ to $300^{\circ} \mathrm{C}$ Versus Percent Aluminum and Iron Hydroxides in Canister Particulate Samples From K-East and K-West Basin Canisters [Sloughter and Barney, 1998].

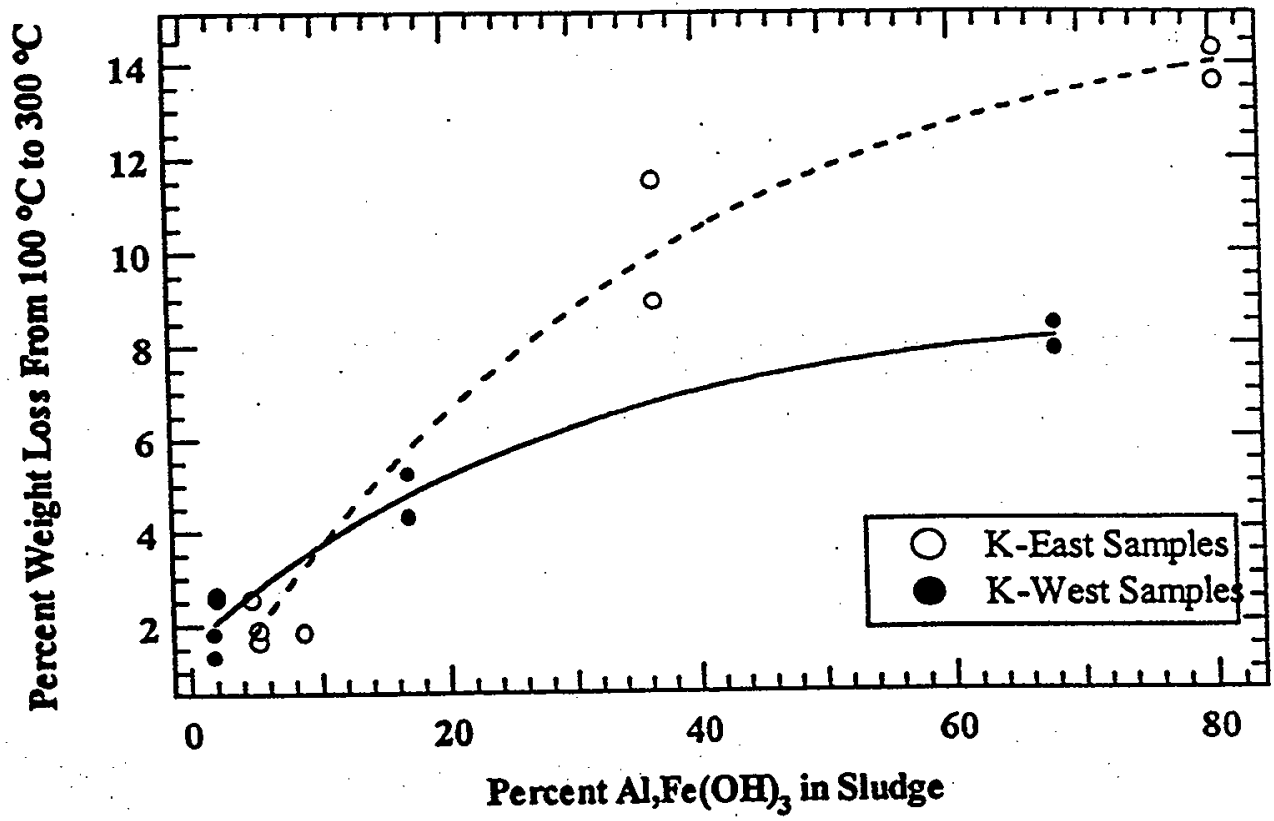




\subsection{K-East Canister Particulate Dryout Data}

Dryout data for K-East canister particulate may be used to estimate the water content of $=:$ canister particulate deposits and adhering particulate. Table 3-2 summarizes weight loss ascribed to uranium oxide hydrates by [Abrefah, et al., 1998]. Their postulated decomposition steps are:

$$
\begin{aligned}
& \mathrm{UO}_{3} 2 \mathrm{H}_{2} \mathrm{O} \rightarrow \mathrm{UO}_{3} \cdot \mathrm{H}_{2} \mathrm{O} \\
& \mathrm{UO}_{3} \cdot \mathrm{H}_{2} \mathrm{O} \rightarrow \mathrm{UO}_{3} \cdot 0.5 \mathrm{H}_{2} \mathrm{O} \\
& \mathrm{UO}_{3} \cdot 0.5 \mathrm{H}_{2} \mathrm{O} \rightarrow \mathrm{UO}_{3}
\end{aligned}
$$

If a canister particulate sample contained only $\mathrm{UO}_{3} \cdot 2 \mathrm{H}_{2} \mathrm{O}$, the maximum water fraction would be $11.1 \%$. Data show that this canister particulate was only partially hydrated in general. An exceptional case is TGA \#45 whose high water content is not explained by the decomposition model. The average water fraction, including TGA $\# 45$, is $7.4 \%$.

\begin{tabular}{|c|c|c|c|c|c|}
\hline \multirow[t]{2}{*}{ TGA Run } & \multicolumn{3}{|c|}{ Mass (mg) } & \multirow{2}{*}{$\begin{array}{l}\text { Weight (mg) } \\
\text { at } 425^{\circ} \mathrm{C}\end{array}$} & \multirow{2}{*}{$\begin{array}{c}\% \text { Weight Hydrate } \\
\text { Water }\end{array}$} \\
\hline & Peak 1 & Peak 2 & Peak 3 & & \\
\hline 40 & 16.38 & 8.19 & 8.19 & 988.04 & $3.3 \%$ \\
\hline 41 & 8.65 . & 4.32 & 4.32 & 655.08 & $2.6 \%$ \\
\hline 42 & 17.36 & 8.7 & 8.66 & 604.64 & $5.7 \%$ \\
\hline 43 & 19.21 & 9.6 & 9.6 & 985.99 & $3.9 \%$ \\
\hline 44 & 17.51 & 8.75 & 8.75 & 324.89 & $10.8 \%$ \\
\hline 45 & 31.34 & 15.7 & 15.63 & 361.25 & $17.3 \%$ \\
\hline 46 & 17.94 & 9.0 & 8.93 & 442.39 & $8.1 \%$ \\
\hline
\end{tabular}

\section{Table 3-2:}

K-East Canister Particulate Hydrate Water Content Based on [Abrefah; et al., 1998]. 


\subsection{TECHNICAL BASES AND ASSUMPTIONS}

Technical bases for MCO water content derived from experimental data and references are summarized here, and assumptions based on these references are listed and supported.

Technical bases formulated from the references are:

1. The particulate estimates of [Sloughter, 1998] comprise a detailed inventory and basis for identification of potentially water-bearing compounds.

2. Consistent with [Sloughter, 1998], high, nominal, and low values of MCO water content will be provided here corresponding to the three reference levels of particulate inventory. High values cannot credibly be exceeded for an entire $\mathrm{MCO}$, although locally higher and lower values of underlying parameters could exist within an MCO. A nominal value is intended to represent a whole $\mathrm{MCO}$ on average, and a low value will occasionally characterize the contents of an MCO.

3. Uranium peroxide hydrates, if present as $\mathrm{UO}_{4} \cdot 4 \mathrm{H}_{2} \mathrm{O}$ prior to $\mathrm{CVD}$, will be decomposed during CVD to $\mathrm{UO}_{4} \cdot 2 \mathrm{H}_{2} \mathrm{O}$, i.e., the water content associated with $\mathrm{UO}_{4}$ hydrates cannot be greater than that associated with $\mathrm{UO}_{3} \cdot 2 \mathrm{H}_{2} \mathrm{O}$. The technical basis is given in Appendix G.

4. K-East canister particulate dryout data [Abrefah, et al., 1998], described in Appendix E, provide a technical basis for particulate water content and drying behavior of $\mathrm{UO}_{3}$ hydrates. These data are consistent with $\mathrm{UO}_{3} \cdot 2 \mathrm{H}_{2} \mathrm{O}$ decomposition and average water contents below the theoretical value for this compound.

Experimental data are interpreted for this work (see Appendix F) to imply: (1) The decomposition half-life range expected at $50^{\circ} \mathrm{C}$ is about 88 hours, (2) Loss of the first mole of water, i.e., decomposition to $\mathrm{UO}_{3} \cdot \mathrm{H}_{2} \mathrm{O}$, may partially occur under CVD conditions but is rate-limited and further decomposition cannot occur at CVD, and (3) A high water content corrosion product associated with reactive metal surfaces is given by that of $\mathrm{UO}_{3} \cdot 2 \mathrm{H}_{2} \mathrm{O}$, or $11 \%$, an average water content is $7.4 \%$ (see Section 3.13 ), and a low value is $3 \%$. 
One instance of a higher water content was seen, but: (a) it is not appropriate to apply this to a whole $\mathrm{MCO}$, and (b) physically this implies the presence of $\mathrm{UO}_{4} \cdot 4 \mathrm{H}_{2} \mathrm{O}$, which by the technical basis will decompose to have no greater water content than that of $\mathrm{UO}_{3} \cdot 2 \mathrm{H}_{2} \mathrm{O}$.

5. Conditions during CVD are either unfavorable or prohibitive to formation of uranium oxide hydrates after MCO water drainage, based upon consideration of equilibrium data (Appendix A). The water vapor partial pressure is high enough to theoretically allow formation of hydrates at the beginning of $\mathrm{CVD}, 100 \%$ relative humidity, and $50^{\circ} \mathrm{C}$, but oxygen should be in insufficient abundance and hydrogen should be in excessive abundance to prohibit the reaction. After partial free water removal, the relative humidity will fall to low values and prohibit hydrate formation.

Further technical basis for this judgement is given by literature data on formation of uranium oxide hydrates and rate law data in Appendix C. For practical purposes, these hydrates are only formed in systems with high relative humidities and high oxygen content. Even in steam-air mixtures at $80^{\circ} \mathrm{C}$ and $80 \%$ relative humidity, less than $10 \%$ molar conversion of oxide to hydrate occurred over a 10 day period when the initial material was very fine ( 0.2 micron) uranium dioxide powder. It is not correct to assign non-negligible conversion rates to oxide films of much lower specific area for durations an order of magnitude shorter in systems with no obvious source of oxygen besides radiolysis, because radiolysis also liberates hydrogen that prevents hydrate formation (see Appendix A).

6. Canister particulate may be assigned a high water content by assuming a composition of $80 \% \mathrm{Al}+\mathrm{Fe}$ hydrate at $30 \%$ water and the remainder $\mathrm{UO}_{3} 2 \mathrm{H}_{2} \mathrm{O}$. This is in accord with the largest $\mathrm{Al}+\mathrm{Fe}$ compound mass fraction (see [Sloughter and Bamey, 1998]) with equal weighting of the two elements and data presented in Appendix I. Note the resulting $26 \%$ water is in excess of the approximately $14 \%$ water for canister particulate with $80 \% \mathrm{Al}+\mathrm{Fe}$ shown in Figure 3-1. Further, the actual inventory of canister particulate presented by [Sloughter, 1998] was developed using a high density of $2.7 \mathrm{~g} / \mathrm{cm}^{3}$. But for derivation of a bounding water content, this value is physically too large. Because the highest bulk density of high water content canister particulate is $1.5 \mathrm{~g} / \mathrm{cm}^{3}$ (see Appendix I), canister particulate mass inventories may be reduced by the ratio $1.5 / 2.7=0.56$ for the purpose of calculating the bounding water content. Thus, the overall fractions of the [Sloughter, 1998] canister particulate inventory used for its bounding water content is $14.5 \%$, rounded to $15 \%$.

7. About $200 \mathrm{~g}$ free water may remain in an MCO after CVD. See [Pajunen, 1998a and 1998b] for the technical basis. 
Assumptions for MCO water inventory estimates are:

1. Adhering particulate (a category in the particulate inventory) is at most $50 \%$ mole fraction hydrated. This assumption is developed further in the calculations section, and stands as an assumption because there are no particulate density data for this category, only bulk density data.

Associated data and equations are contained in Appendix I. Summarizing the logic of this assumption, the bulk density of this material exceeds the bulk density of K-East canister particulate samples, and the particle density associated with high bulk density K-East canister particulate exceeds the hydrate theoretical density. Therefore, this particulate can only be partially hydrated.

2. Thermal decomposition of $\mathrm{Al}(\mathrm{OH})_{3}$ and $\mathrm{Fe}(\mathrm{OH})_{3}$ will be negligible during CVD. This is supported by data for crystaline forms (see [Sloughter and Barney, 1998]) and is conservative for the present purpose. For $\mathrm{Al}(\mathrm{OH})_{3}$, limited data shown in Appendix B also support this assumption.

3. Canister particulate may be assigned a nominal water content of $7.5 \%$ in accord with the data of Abrefah reported in Section 3.13. Because the relative proportion of water from $\mathrm{U}$ or $\mathrm{Al}+\mathrm{Fe}$ hydrates is not known, a weighting of $75 \%$ from $\mathrm{U}$ hydrates and $25 \%$ from $\mathrm{Al}+\mathrm{Fe}$ hydrates is chosen, corresponding to the $72 \%$ by weight of $U$ compounds in this material cited by [Sloughter and Barney, 1998]. 


\subsection{CALCULATIONS .}

\subsection{Cladding Surface Films}

Cladding surface film inventories from [Sloughter, 1998] employed a combination of aluminum hydroxide and uranium peroxide hydrate as follows: High, pure $\mathrm{Al}(\mathrm{OH})_{3}$; Nominal, $25 \% \mathrm{Al}(\mathrm{OH})_{3}, 75 \% \mathrm{UO}_{4} 4 \mathrm{H}_{2} \mathrm{O}$; Low, pure $\mathrm{UO}_{4} 4 \mathrm{H}_{2} \mathrm{O}$. As described in Section 3, $\mathrm{Al}(\mathrm{OH})_{3}$ may not thermally decompose at $\mathrm{CVD}$, so a water content of $35 \%$ applies. $\mathrm{UO}_{4} 4 \mathrm{H}_{2} \mathrm{O}$ will easily decompose to $\mathrm{UO}_{4} 2 \mathrm{H}_{2} \mathrm{O}$, so a water content of $11 \%$ applies.

\subsection{Oxide Films on Scrap and Fuel}

Oxide film masses of Table 3-1 were calculated assuming a density of $10 \mathrm{~g} / \mathrm{cc}$, equivalent to $\mathrm{UO}_{2}$ at slightly less than theoretical density. As seen in Appendix I, the density of a hydrate is less than half that value, and the dominant hydrate expected to form based on Appendix $\mathrm{C}$ is $\mathrm{UO}_{3} \cdot 2 \mathrm{H}_{2} \mathrm{O}$. Thus, the oxide mass may be multiplied by a factor of $0.5 * 0.11=0.055$ or $5.5 \%$ to yield a high water content for these contributions. This weight fraction also applies to any $\mathrm{UO}_{4} \cdot 4 \mathrm{H}_{2} \mathrm{O}$, as discussed in Appendix G. Per the discussion in Appendix F, no credit is taken for decomposition of uranium oxide hydrates during CVD. A nominal water content is the average of Abrefah's data, about 7.5\% [Abrefah, et al., 1998], again adjusted by a factor of 0.5 for the density, yielding a rounded value of $4 \%$. Taking a low value of $3 \%$ similarly yields a low end water content of $1.5 \%$. 


\subsection{Particulate on Scrap and Fuel}

Particulate found on scrap and fuel listed in Table 3-1 is based upon measurements of the $=$ mass of particles that could be scraped and picked from metal fuel surfaces and underneath cladding adjacent to exposed surfaces, i.e., these particles tenaciously resisted handling and cleaning. Because the metal oxide tends to slough off after a thickness of about 3 microns is attained [Marschman, Pyecha, and Abrefah, 1997], and because the hydrate has an even lower density and should slough of too, and because of the high bulk density of tenacious particulate (Appendix 1 ), it is assumed here that these particles are similar to the densest particles observed in canister particulate. From the data presented in Appendix I, a particle having the maximum observed particle density, $7.88 \mathrm{~g} / \mathrm{cc}$, if consisting of a mixture of hydrate at $5 \mathrm{~g} / \mathrm{cc}$ and metal at $19 \mathrm{~g} / \mathrm{cc}$ (a conservative combination) would have a hydrate mass fraction $\mu$ given by

$$
\frac{1}{7.88}=\frac{\mu}{.5}+\frac{1-\mu}{19}
$$

resulting in $\mu=50 \%$. If instead a mixture of hydrate and oxide were postulated, then the hydrate content would only be $33 \%$. Since there is no reason for metal to appear in the form of a particle firmly attached to the surface, and since metal particles would be reacted anyway, it is more reasonable to assume that the observed particles are mostly oxide. Given the high density of particles that could adhere to surfaces, it is clear that only a fraction of these particles can be hydrate. It is assumed that a hydrate fraction of $50 \%$ is a conservative upper bound.

Given $50 \%$ hydrate consisting of $11 \%$ water, $5.5 \%$ is assigned to the high water fraction for particulate found on fuel and scrap. The nominal and low water fraction values are found using Abrefah's data, as discussed for oxide film, and are numerically equal to those for oxide film, 4 and $1.5 \%$, respectively. 


\subsection{Canister Particulate}

Nominal values for canister particulate follow from mass fraction values cited by [Sloughter and Barney, 1998] and discussed in Section 3, namely, $12 \% \mathrm{Al}(\mathrm{OH})_{3}, 13 \% \mathrm{Fe}(\mathrm{OH})_{3}$, and $75 \%$ uranium corrosion product by difference. While the water contents of $\mathrm{Al}(\mathrm{OH})_{3}$ and $\mathrm{Fe}(\mathrm{OH})_{3}$ are $35 \%$ and $25 \%$, respectively, it is clear from Figure 3-1 that no more than about 7\% water can be expected in canister particulate with a $25 \% \mathrm{Al}+\mathrm{Fe}$ content. A water content of 7.5\% may be used for canister particulate to be consistent with the average of Abrefah's data cited above, and with no density correction needed. Since the data do not provide a means to partition water among $\mathrm{U}$ and $\mathrm{Al}+\mathrm{Fe}$ (note $25 \% \mathrm{Al}+\mathrm{Fe}$ hydraies yields $7.5 \% \mathrm{H}_{2} \mathrm{O}$ ), $25 \%$ is assumed from $\mathrm{Al}+\mathrm{Fe}$ and $75 \%$ from $\mathrm{U}$.

High values are obtained by noting weight loss data of Figure 3-1 and composition data presented in Appendix I, which show that canister particulate may contain more aluminum and iron compounds than uranium compounds. But water loss below $100^{\circ} \mathrm{C}$ and above $300^{\circ} \mathrm{C}$ are not included in the data, and $80 \% \mathrm{Al}+\mathrm{Fe}$ hydrate implies $24 \%$ water. Adding $20 \%$ uranium hydrate at $11 \%$ water yields a high water content of $26 \%$. As noted in Appendix I, the highest bulk density of high water content canister sludge is $1.5 \mathrm{~g} / \mathrm{cm}^{3}$. However, [Sloughter, 1998] calculated the amount of canister particulate using a density of $2.7 \mathrm{~g} / \mathrm{cm}^{3}$. It is not appropriate to combine a high water content with a high bulk density, as already discussed with regard to oxide films in Section 5.2. Canister particulate with a high water content must have a low density, so that the bounding canister particulate inventory from Table 3-1 should be reduced by a factor of at least $1.5 / 2.7=0.56$ prior to calculation of water inventory. Therefore an overall factor of $(26 \%)$ $(0.56)=14.5 \%$, or $15 \%$ when rounded, may be used to calculate the bounding water content of canister particulate from the reference particulate mass values listed in Table 3-1. Note that the uranium compound mass fraction is $20 \%$, but the fraction of water from uranium compounds is $2 \% / 26 \%=0.077$, or about $8 \%$. 
A low value of $2 \%$ water fraction is selected from Figure 3-1 and ascribed entirely to uranium oxide hydrates.

\subsection{Generated Particulate}

As noted in Section 3.1, a bounding value for generated particulate through the end of CVD is about $25 \mathrm{~kg}$. However, as discussed in Appendix A, hydrate formation cannot occur when oxygen is absent and hydrogen is present, as would be the case after MCO drainage. Therefore, a high value of water content from generated particulate need only consider particulate generated up to the time of MCO drainage, for which a bounding value of $15 \mathrm{~kg}$ and a nominal value of $0.075 \mathrm{~kg}$ apply.

Considering $60^{\circ} \mathrm{C}$ rate data in Appendix $\mathrm{C}$ to bound conversion of oxide to hydrate, a conversion fraction of $5 \%$ is appropriate. Because the hydrate water fraction is $11 \%$, the overall high water fraction for generated particulate is $0.55 \%$. When applied to the $15 \mathrm{~kg}$ bounding generated particulate mass, this results in only $0.083 \mathrm{~kg}$ water, and the nominal generated particulate mass would bear less than 1 gram water.

Thus, water chemically bound to generated particulate may be neglected for all but the high particulate cases. Bounding areas used by [Sloughter, 1998] are $4.5 \mathrm{~m}^{2}$ per scrap basket and $0.79 \mathrm{~m}^{2}$ per fuel basket, so an area ratio may be applied to the $15 \mathrm{~kg}$ generated particulate mass calculated for two scrap and three fuel baskets to yield high values with one and zero scrap baskets. These area ratios are 0.64 and 0.35 , respectively. For an MCO with one scrap basket, $9.6 \mathrm{~kg}$ of generated particulate would bear $0.053 \mathrm{~kg}$ water. For an MCO with no scrap basket, $5.25 \mathrm{~kg}$ generated particulate would bear $0.029 \mathrm{~kg}$ water. 


\subsection{Summary of Water Inventory}

Table 5-1 contains a summary of the MCO particulate water inventory based on line-item=: particulate sources from Table 3-1, and Table 5-2 contains a similar summary based on compound source. In all cases, 200 grams free water are considered because this amount may remain when an MCO is declared dry. 
HNF-1523, Rev 1

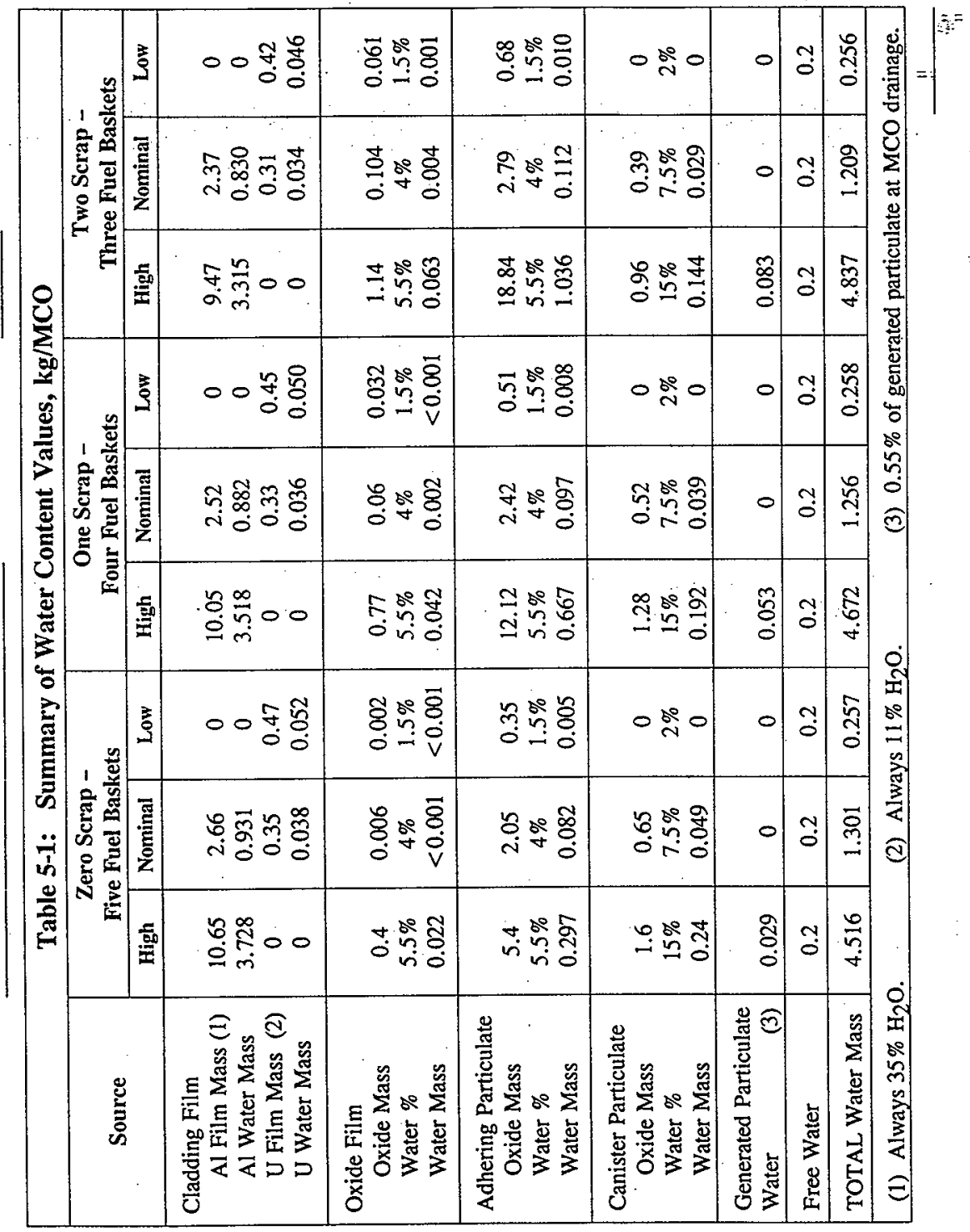


HNF-1523, Rev 1

Table 5-2: Post-CVD Particulate Water Content Summary (kg)

\begin{tabular}{|c|c|c|c|c|}
\hline Source & & High & Nominal & Low \\
\hline \multicolumn{5}{|l|}{ Zero Scrap, Five Fuel } \\
\hline $\mathrm{Al}(\mathrm{OH})_{3}$ & (1) & 3.728 & 0.931 & 0 \\
\hline Uranium Oxide Hydrates & (2) & 0.367 & 0.158 & 0.057 \\
\hline $\mathrm{Al}+\mathrm{Fe}$ Hydrates & (3) & 0.221 & 0.012 & 0 \\
\hline Free & & 0.2 & 0.2 & 0.2 \\
\hline TOTAL & & 4.516 & 1.301 & 0.257 \\
\hline \multicolumn{5}{|l|}{ One Scrap, Four Fuel } \\
\hline $\mathrm{Al}(\mathrm{OH})_{3}$ & (1) & 3.518 & 0.882 & 0 \\
\hline Uranium Oxide Hydrates & (2) & 0.777 & 0.164 & 0.058 \\
\hline $\mathrm{Al}+\mathrm{Fe}$ Hydrates & (3) & 0.177 & 0.01 & 0 \\
\hline Free & & 0.2 & 0.2 & 0.2 \\
\hline TOTAL & & 4.672 & 1.256 & 0.258 \\
\hline \multicolumn{5}{|l|}{ Two Scrap, Three Fuel } \\
\hline $\mathrm{Al}(\mathrm{OH})_{3}$ & (1) & 3.315 & 0.830 & 0 \\
\hline Uranium Oxide Hydrates & (2) & 1.189 & 0.172 & 0.056 \\
\hline $\mathrm{Al}+\mathrm{Fe}$ Hydrates & (3) & 0.133 & 0.007 & 0 \\
\hline Free & & 0.2 & 0.2 & 0.2 \\
\hline \multicolumn{2}{|c|}{ TOTAL } & 4.837 & 1.209 & 0.256 \\
\hline \multicolumn{5}{|c|}{$\begin{array}{l}\text { (1) Cladding Film; High }=100 \% \text { from } \mathrm{Al}(\mathrm{OH})_{3} \text {, Nominal }=51 \% \text { from } \\
\mathrm{Al}(\mathrm{OH})_{3} \text {, and Low }=0 \% \text { from } \mathrm{Al}(\mathrm{OH})_{3} \text {. }\end{array}$} \\
\hline \multicolumn{5}{|c|}{$\begin{array}{l}\text { (2) Cladding Film, Oxide Film, Adhering Particulate, and Canister Particulate. } \\
\text { (3) Canister Particulate; High }=92 \% \text { from } \mathrm{Al}+\mathrm{Fe} \text { hydrates, Nominal }=25 \% \\
\text { from } \mathrm{Al}+\mathrm{Fe} \text { hydrates. }\end{array}$} \\
\hline
\end{tabular}




\subsection{REFERENCES}

J. Abrefah, H. C. Buchanan, and S. C. Marschman, "Drying Behavior of K-East Canister Sludge," PNNL-11628, UC-602, Pacific Northwest National Laboratory, Richland, WÄ, May 1998.

J. Danroc, "Evolution Superficielle et Aptitude au Compactage des Poudres de Dioxyde d'Uranium," Doctoral Thesis, l'Institut National Polytechnique de Grenoble, April 1982.

Duncan, D.R., and Ball, D.E., "Thermal Analysis of Cold Vacuum Drying of Spent Nuclear Fuel," HNF-SD-SNF-CN-023, Rev. 0, DE\&S Hanford, Richland, WA, 1997.

Garvin, L.J., "Canister Storage Building Safety Analysis Report," HNF-SD-SNF-RPT-044, Rev. 7, May 1997.

J. Irwin, "Cold Vacuum Drying Facility Design Requirements," HNF-SD-SNF-DRD-002, Rev. 1, Numatech Hanford Company, September 1997.

Marschman, S.C., and Abrefah, J., "Highlight Report: Water Content of Film Coatings on KEast Fuel Surfaces," SNFCT97:040:R00, March 1997.

Marschman, S.C., Pyecha, and Abrefah, J., "Metallographic Examination of Damaged N Reactor Spent Nuclear Fuel Element SFEC5.4378," PNNL-11438, UC-602, August 1997.

Plys, M.G., et al., "Hanford Spent Nuclear Fuel Safety Analysis Model: .User's Manual," FAI/97-36, Rev. 1, Fauske \& Associates, Inc., Burr Ridge, Illinois, 1997.

T. Sato, "Preparation of Uranium Peroxide Hydrates," J. Appl. Chem., Vol. 13, August 1963, pp. 361-365.

J.P. Sloughter, "Estimates of Particulate Mass in Multi-Canister Overpacks," HNF-1527, Rev. 2, Numatec Hanford Corporation, Richland, WA, October 1998.

Sloughter, J.P., and Barney, G.S., "Identities of Compounds in Spent Nuclear Fuel Coatings and Particulates Sealed in Multi-Canister Overpacks," HNF-2667, Rev. 1 (Draft), Numatec Hanford Corporation, Richland, WA, July 1998.

P. Taylor, R. J. LeMire, and D. W. Wood, "The Influence of Moisture on Air Oxidation of $\mathrm{UO}_{2}$ : Calculations and Observations," Nucl. Tech., Vol. 42, Nov. 1993, pp. 164-170. 


\section{APPENDIX A \\ THERMODYNAMIC DATA AND IMPLICATIONS}

\section{A.1 Purpose and Summary}

The purpose of this Appendix is to conveniently summarize thermodynamic data for species of concern to the MCO water inventory, and use these data to describe limitations on the formation and decomposition of hydrates for conditions pertinent to the K-basins, cold vacuum drying, and dry storage.

The equilibrium vapor pressure curve for decomposition of $\mathrm{UO}_{3} \cdot 2 \mathrm{H}_{2} \mathrm{O}$ is very close to that of water vapor over water. The hydrogen pressure to prevent hydrate formation is orders of magnitude less than the oxygen pressures needed for formation, indicating that radiolysis of water vapor would prohibit formation.

The hydrogen partial pressure is actually determined by competing rates: Formation by oxidation of reactive uranium surfaces by water, and removal by convection. Evaluation of the hydrogen partial pressure is a moot point because any result must be many of orders of magnitude greater than the equilibrium value to prevent hydrate formation.

Uranium hydrates can only form in an MCO when reactive surface area is present, so the presence of oxide as a precursor to hydrate is perfectly correlated with the presence of reactive metal for oxidation by water vapor.

During cold vacuum drying, if there is a reactive metal surface present, uranium dioxide will form and this material in turn could potentially be converted into hydrate. However, the local partial pressure of hydrogen gas is always sufficient to prevent this reaction.

Therefore, $\mathrm{UO}_{3}$ hydrates cannot form in an $\mathrm{MCO}$ during cold vacuum drying after removal of the oxygen initially present. 
The presence of hydrogen similarly prevents formation of other $\mathrm{UO}_{3}$ hydrates. As shown in Appendix C, these other hydrates simply do not form unless the local temperature is close to about $100^{\circ} \mathrm{C}$ anyway, and at CVD temperatures only $\mathrm{UO}_{3} \cdot 2 \mathrm{H}_{2} \mathrm{O}$ would be observed as a $=$ : reaction product.

Insufficient thermodynamic data exist on the $\mathrm{UO}_{4}$ hydrates for conclusions to be drawn on this basis alone, and literature concerning observed formation and decomposition is summarized in Appendix G.

\section{A.2 Uranium Oxide Hydrate Thermodynamic Data}

Thermodynamic data are taken from JANAF [Chase, et al., 1985], [Katz, Seaborg, and Morss, 1986], [Taylor, et al., 1993], and [O'Hare, et al., 1988]. Table A-1 summarizes these data and includes estimates for $\mathrm{UO}_{3} \cdot 0.8 \mathrm{H}_{2} \mathrm{O}$. Multiple data sources for the same compound are included so that values may be compared. . We deduce that $\mathrm{UO}_{3} \cdot \mathrm{H}_{2} \mathrm{O}$ from [Katz, Seaborg, and Morss, 1986] corresponds to $\beta-\mathrm{UO}_{2}(\mathrm{OH})_{2}$ from [Taylor, et al., 1993], and that values for $\mathrm{UO}_{3} \cdot 2 \mathrm{H}_{2} \mathrm{O}$ are in accord between these two references. The heat of formation for $\mathrm{UO}_{3} \cdot 0.8 \mathrm{H}_{2} \mathrm{O}$ was deduced by noting a linear variation in this parameter with water content, and its entropy of formation was deduced similarly.

Sufficient data exists to construct equilibrium decomposition curves for the $\mathrm{UO}_{3} \cdot \mathrm{xH}_{2} \mathrm{O}$ family. These are presented here as Figure A-1 [Plys, 1997]. Entropy data are lacking for $\mathrm{UO}_{4} \times \mathrm{xH}_{2} \mathrm{O}$ compounds, but [Cordfunke, 1978] and [O'Hare, et al., 1988] provide the following vapor pressure curve:

$$
\begin{aligned}
& \mathrm{UO}_{4} \cdot 4 \mathrm{H}_{2} \mathrm{O} \rightarrow \mathrm{UO}_{4} \cdot 2 \mathrm{H}_{2} \mathrm{O}+2 \mathrm{H}_{2} \mathrm{O} \\
& \log _{10}(\mathrm{P})=8.055-\frac{3056}{\mathrm{~T}}
\end{aligned}
$$

where $\mathrm{P}$ is in atmospheres. 


\begin{tabular}{|c|c|c|c|c|c|c|}
\hline \multicolumn{7}{|c|}{ Table A-1: } \\
\hline Compound & $\underset{\mathrm{kJ} / \mathrm{mol}}{\Delta \mathbf{H}_{\mathrm{f}}}$ & $\stackrel{\mathbf{s}}{\mathrm{J} / \mathrm{mol}}$ & $\underset{\mathrm{J} / \mathrm{mol} \cdot \mathrm{K}}{\mathbf{c}_{p}}$ & $\underset{\mathrm{J} / \mathrm{mol} \cdot \mathrm{K}}{\Delta \mathrm{S}_{\mathrm{f}}}$ & $\underset{\mathrm{kJ} / \mathrm{mol}}{\Delta \mathbf{G}_{\mathrm{f}}}$ & Ref. \\
\hline $\mathrm{H}_{2}$ & 0 & $130: 68$ & 28.836 & 0 & 0 & 2 \\
\hline $\mathrm{O}_{2}$ & 0 & 205.15 & 29.38 & 0 & 0 & 2 \\
\hline$U$ & 0 & 50.2 & 27.66 & 0 & 0 & 1 \\
\hline $\mathrm{H}_{2} \mathrm{O}(\mathrm{g})$ & -241.83 & 188.83 & 33.59 & $(-44.43)$ & -228.58 & 2 \\
\hline $\mathrm{H}_{2} \mathrm{O}(\ell)$ & -285.83 & 69.95 & 75.35 & $(-163.31)$ & -237.14 & 2 \\
\hline $\mathrm{UO}_{2}$ & -1085.0 & 77.03 & 63.60 & . & -1031.8 & 1 \\
\hline $\mathrm{UO}_{3}$ & -1223.8 & 96.11 & 81.7 & $(-261.8)$ & $(-1145.8)$ & 1 \\
\hline $\mathrm{UO}_{3}$ & & 96.11 & 81.7 & & -1145.7 & 3 \\
\hline $\mathrm{UO}_{3} \cdot \mathrm{H}_{2} \mathrm{O}$ & -1533 & 134 & & $(-457.2)$ & -1397 & 1 \\
\hline$\beta-\mathrm{UO}_{2}(\mathrm{OH})_{2}$ & $(-1534)$ & 138 & 141 & $(-453.2)$ & -1398.7 & 3 \\
\hline $\mathrm{UO}_{3} \cdot 2 \mathrm{H}_{2} \mathrm{O}$ & -1827 & 176 & & & & 1 \\
\hline $\mathrm{UO}_{3} \cdot 2 \mathrm{H}_{2} \mathrm{O}$ & $(-1826)$ & 188.54 & 172 & $(-635.9)$ & -1636.5 & 3 \\
\hline $\mathrm{UO}_{3}-0.9 \mathrm{H}_{2} \mathrm{O}$ & $(-1506.3)$ & 126 & 140 & $(-441.9)$ & -1374.6 & 3 \\
\hline $\mathrm{UO}_{3}-0.85 \mathrm{H}_{2} \mathrm{O}$ & -1492 & & & & & 1 \\
\hline $\mathrm{UO}_{3}-0.8 \mathrm{H}_{2} \mathrm{O}$ & $(-1477)$ & $(120)$ & (140) & & & \\
\hline $\mathrm{UO}_{3}-0.85 \mathrm{H}_{2} \mathrm{O}$ & -1491.4 & 123 & & & -1362.3 & 4 \\
\hline $\mathrm{UO}_{3} \cdot 0.6 \mathrm{H}_{2} \mathrm{O}$ & -1424.6 & 118 & & & -1308.1 & 4 \\
\hline $\mathrm{UO}_{4} \cdot 2 \mathrm{H}_{2} \mathrm{O}$ & -1782 & & & & & 1 \\
\hline $\mathrm{UO}_{4} \cdot 4 \mathrm{H}_{2} \mathrm{O}$ & -2384 & & & & & 1 \\
\hline \multicolumn{7}{|c|}{ References: } \\
\hline \multicolumn{7}{|c|}{ Katz, Seaborg, \& Morss, 1986} \\
\hline 2 & \multicolumn{6}{|c|}{ Chase, et al., 1985} \\
\hline 3. & \multicolumn{6}{|c|}{ Taylor, et al., 1993.} \\
\hline 4. & \multicolumn{6}{|c|}{ O'Hare, et al., 1988.} \\
\hline
\end{tabular}


Figure A-1: Equilibrium Decomposition Curves for the $\mathrm{UO}_{3} \times \mathrm{xH}_{2} \mathrm{O}$ Family.

VAPOR PRESSURE CURVES USING BOUNOING ENTROPY VALUES ARE RECOMMENDED TO PRESERVE THE TRANSITIVE NATURE OF THE CURVES WITH STOICHIOMETRY NUMBER

$\operatorname{Ln}(P)=A+B / T$ yialds:

U03.2 $\mathrm{H} 2 \mathrm{O}$ to UO3.H2O:

UO3. $\mathrm{H} 2 \mathrm{O}$ to U03.0.5 $\mathrm{H} 2 \mathrm{O}$ :

UO3.0.5H2O to UO3:
A

15.912

18.382

18.408
B note $P$ in atm!

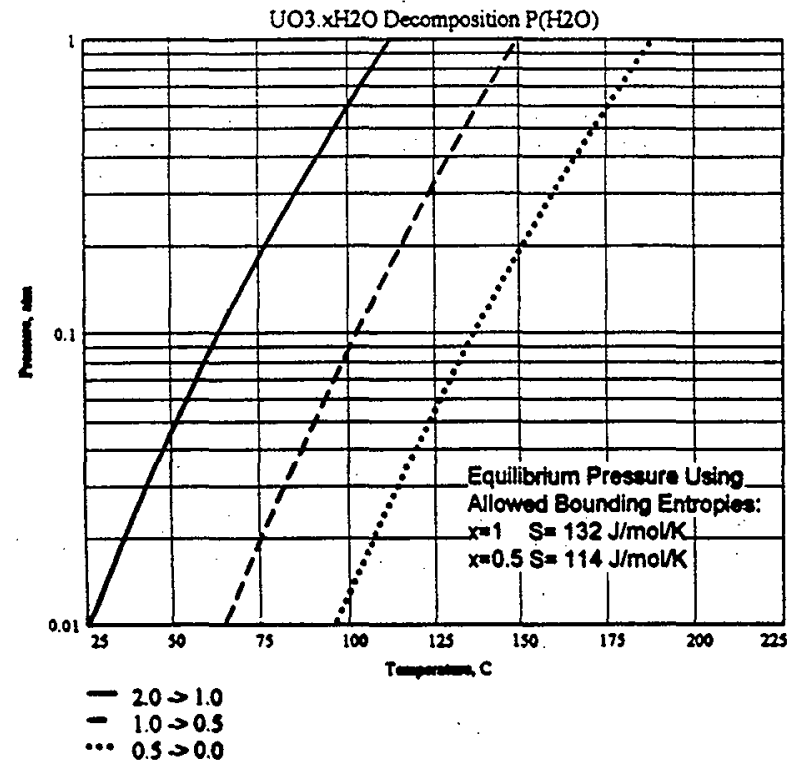




\section{A.3 UO3 Hydrate Thermodynamic Data Implications}

The fact that some oxygen must be present to allow formation of $\mathrm{UO}_{3}$ hydrates is evident $=:$ from the negative free energy change for a reaction with oxygen present and the positive free energy change for a reaction with oxygen absent:

$$
\begin{aligned}
& \mathrm{UO}_{2}+1 / 2 \mathrm{O}_{2}+2 \mathrm{H}_{2} \mathrm{O} \rightarrow \mathrm{UO}_{3} \cdot 2 \mathrm{H}_{2} \mathrm{O}, \Delta \mathrm{G}=-147.5 \mathrm{~kJ} / \mathrm{mol} \\
& \mathrm{UO}_{2}+3 \mathrm{H}_{2} \mathrm{O} \rightarrow \mathrm{UO}_{3} \cdot 2 \mathrm{H}_{2} \mathrm{O}+\mathrm{H} 2, \Delta \mathrm{G}=+81 \mathrm{~kJ} / \mathrm{mol}
\end{aligned}
$$

The implication of these equations is that there is some equilibrium oxygen concentration at which hydrate formation becomes thermodynamically permissible.

For the first reaction above,

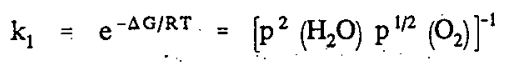

at $25^{\circ} \mathrm{C}$, yields $\mathrm{k}_{1}=7.17 \times 10^{25}$ and setting $\mathrm{p}\left(\mathrm{H}_{2} \mathrm{O}\right)=0.03 \mathrm{~atm}$, the saturation value, yields $\mathrm{p}\left(\mathrm{O}_{2}\right)=4 \times 10^{-12} \mathrm{~atm}$.

But the second reaction yields the hydrogen pressure required to prohibit formation of the hydrate:

$$
k_{2}=\frac{p\left(\mathrm{H}_{2}\right)}{p^{3}\left(\mathrm{H}_{2} \mathrm{O}\right)}
$$

At $25^{\circ} \mathrm{C} \mathrm{k}_{2}=6.3 \times 10^{-15}$, so with $\mathrm{p}\left(\mathrm{H}_{2} \mathrm{O}\right)=0.03 \mathrm{~atm}, \mathrm{p}\left(\mathrm{H}_{2}\right)=1.7 \times 10^{-19} \mathrm{~atm}$.

The hydrogen partial pressure to prevent hydrate formation is so low that it is absolutely clear that the threshold is exceeded when uranium is locally reacting with water to form hydrogen. 


\section{A.4 References}

M. W. Chase, et al., "JANAF Thermochemical Tables," Third Edition, J. Phys. Ref. Data, Vol. 14, 1985, Supplement 1.

E. H. P. Cordfunke, "The Chemical Thermodynamics of Actinide Elements and Compounds; Part 3: Miscellaneous Actinide Compounds," IAEA, Vienna, 1978.

J. J. Katz, G. T. Seaborg, and L. R. Morss, "The Chemistry of the Actinide Elements," Second Edition, Chapman and Hall, New York, 1986.

P. A. G. O'Hare, B. M. Lewis, and S. N. Nguyen, "Thermochemistry of Uranium Compounds XVII: Standard Molar Enthalpy of Formation at $298.15 \mathrm{~K}$ of Dehydrated Schoepite $\mathrm{UO}_{3} \cdot 0.9 \mathrm{H}_{2} \mathrm{O}$," Thermodynamics of (schoepite + dehydrated schoepite + water), J. Chem. Thermodynamics, 1988, Vol. 20, pp.1287-1296.

M. Plys, FAI Memorandum to J. Abrefah (PNNL), and D. Duncan and J. Swenson (DE\&SH), "Hydrate Decomposition Vapor Pressures, dated August 26, 1997.

P. Taylor, R. J. LeMire, and D. W. Wood, "The Influence of Moisture on Air Oxidation of $\mathrm{UO}_{2}$ : Calculations and Observations," Nucl. Tech., Vol. 42, Nov. 1993, pp. 164-170. 


\section{APPENDIX B \\ THERMO-GRAVIMETRIC ANALYSIS OF Al(OH) 3 COATING}

Figures B-1 and B-2 contain thermo-gravimetric analysis drying results from coating sample CS-4 which consists predominately of $\mathrm{Al}(\mathrm{OH})_{3}$. These data are taken from the reference below and presented here because they are not yet available in final published form. These data were taken by PNNL in the 325 Building laboratories.

\section{Reference}

B. J. Makenas to R. P. Omberg, "Data from the Analysis of Cladding Coatings and Internal Sludge," DE\&S Hanford Internal Memorandum, dated April 20, 1998. 
Figure B-1: Thermo-Gravimetric Analysis Drying Results from Coating Sample CS-4.

$$
\begin{gathered}
0.4^{\circ} \mathrm{C} / \mathrm{min} \text {. heating rate } \\
10^{-3} \cdot \text { torr vacuum }
\end{gathered}
$$

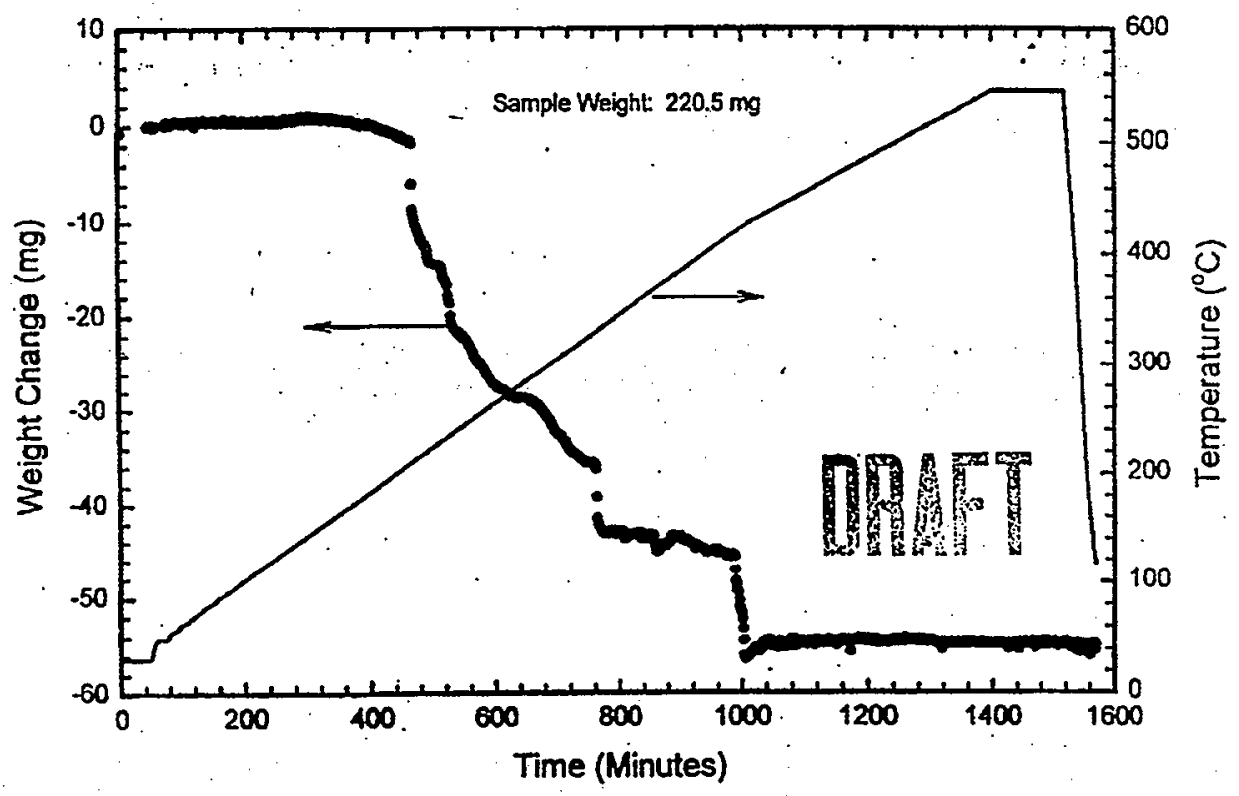


Figure B-2: Duplicate Thermo-Gravimetric Analysis Drying Data from Coating Sample CS-4.

$0.4^{\circ} \mathrm{C} / \mathrm{min}$. heating rate

$10^{-3}$ torr vacuum

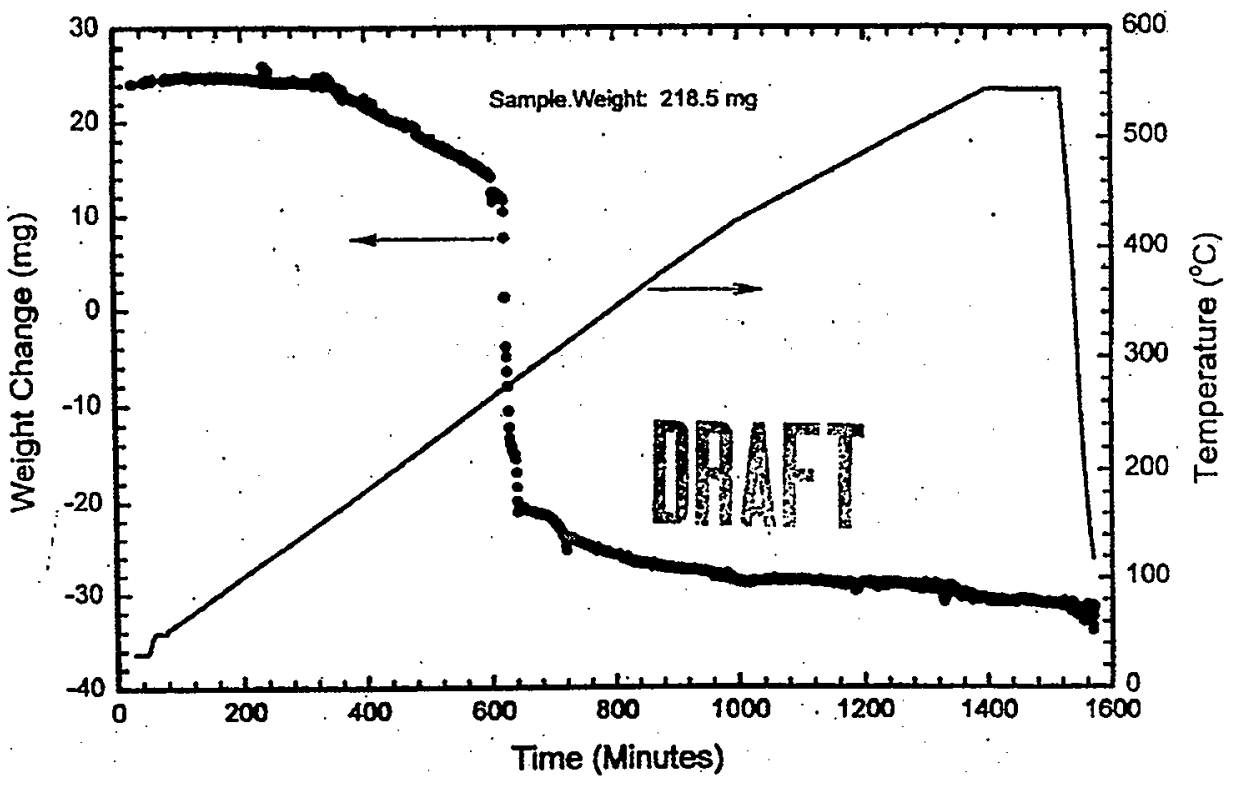




\section{APPENDIX C \\ URANIUM TRIOXIDE HYDRATE FORMATION}

\section{C.1 Purpose and Summary}

The purpose of this Appendix is to summarize literature data regarding the conditions and rates of formation of $\mathrm{UO}_{3}$ hydrates, principally $\mathrm{UO}_{3} \cdot 2 \mathrm{H}_{2} \mathrm{O}$. Literature regarding formation agree universally that either oxygenated water or steam-air environments are required.

\section{C.2 Formation Conditions}

Literature discussing the formation of $\mathrm{UO}_{3}$ hydrates universally describes the required conditions as either oxygenated water or steam/air environments. [Taylor, et al., 1993] writes:

"The formation of $\mathrm{DS}$ [Dehydrated schoepite, $\mathrm{UO}_{3} \mathrm{O} .9 \mathrm{H}_{2} \mathrm{O}$ ] by oxidation of $\mathrm{UO}_{2}$ in oxygenated water at temperatures from $87^{\circ} \mathrm{C}$ to $177^{\circ} \mathrm{C}$ was first reported by Aronson. More recent situdies have confirmed that this phase is a common oxidation product on unused $\mathrm{UO}_{2}$ fuel oxidized in either aerated water or aerated steam (above $\sim 50 \%$ steam saturation) at temperatures near $200^{\circ} \mathrm{C} \ldots$ "

Taylor, et al., also describe experience with long-term (on order years) formation of $\mathrm{UO}_{3} \cdot 2 \mathrm{H}_{2} \mathrm{O}$ during storage in laboratory air and air-saturated water at room temperature.

Observations of [Danroc, 1982] are consistent with Taylor, et al.'s discussion and references. Danroc used $\mathrm{UO}_{2}$ powders of submicron size, about 0.2 micron diameter, and found that exposure to steam-air mixtures of $80 \%$ relative humidity at $60^{\circ} \mathrm{C}$ and $80^{\circ} \mathrm{C}$ resulted in partial conversion of the powder to $\mathrm{UO}_{3} \cdot 2 \mathrm{H}_{2} \mathrm{O}$ during the course of a number of days. At $100^{\circ} \mathrm{C}$, his hydrate product was $\mathrm{UO}_{3}-8.85 \mathrm{H}_{2} \mathrm{O}$. 
$\mathrm{UO}_{3}$ hydrates are also commonly formed by exposing anhydrous $\mathrm{UO}_{3}$ to liquid or vapor water as exemplified by the work and references of [Hoekstra and Siegel, 1973].

\section{C.3 Formation Rate}

The only available formation rate data are those of Danroc, and his low-temperature data are summarized in Figure $\mathrm{C}-1$. It is seen that formation is faster at the higher temperature, but after 10 days the molar conversion is only about $8 \%$. During the portion of cold vacuum drying (CVD) with high relative humidity and a nominal operating temperature of $50^{\circ} \mathrm{C}$, conditions are closer to those of the $60^{\circ} \mathrm{C}$ data, and less than $5 \%$ conversion on a molar basis would be expected for durations on the order of only a day. As mentioned above, Danroc's data were taken with finely divided 0.2 micron $\mathrm{UO}_{2}$ powder, so formation of hydrates should take place even more slowly during CVD.

[Katz and Rabinowitch, 1951] mention existence of Manhattan project data on rates of hydration, but provide no quantitative information.

\section{C.4 Other Uranium Oxide Hydrates}

Two other uranium oxide hydrates, $\beta-\mathrm{UO}_{2}(\mathrm{OH})_{2}$ and $\mathrm{U}_{3} \mathrm{O}_{8}(\mathrm{OH})_{2}$, are discussed by [Taylor, et al., 1993] and [Hoekstra and Siegel, 1973]. These apparently do not form directly from $\mathrm{UO}_{2}$, but either from hydration of $\mathrm{UO}_{3}$ or decomposition of $\mathrm{UO}_{3} \cdot 2 \mathrm{H}_{2} \mathrm{O}$. According to [Taylor, et al., 1993],

"Although the calculated stability relationships indicate narrow stability fields for both $\mathrm{\beta}-\mathrm{UO}_{2}(\mathrm{OH})_{2}$ and $\mathrm{U}_{3} \mathrm{O}_{8}(\mathrm{OH})_{2}$, neither of these phases has been observed as an oxidation product on $\mathrm{UO}_{2}$, nor as a natural mineral. The compound $\beta$ $\mathrm{UO}_{2}(\mathrm{OH})_{2}$ can be synthesized by contacting water with $\mathrm{UO}_{3}$ or $\mathrm{UO}_{3} 2 \mathrm{H}_{2} \mathrm{O}$ at $200^{\circ} \mathrm{C}$ to $290^{\circ} \mathrm{C}$ in a sealed vessel, whereas $\left[\mathrm{UO}_{3} \mathrm{O} .9 \mathrm{H}_{2} \mathrm{O}\right.$ ] is formed at $80^{\circ} \mathrm{C}$ to $200^{\circ} \mathrm{C}$." 
Figure C-1: Danroc's $\mathrm{UO}_{3} \cdot 2 \mathrm{H}_{2} \mathrm{O}$ Formation Data:

Aging of Submicron $\mathrm{UO}_{2}$ Powder in Humid Air.

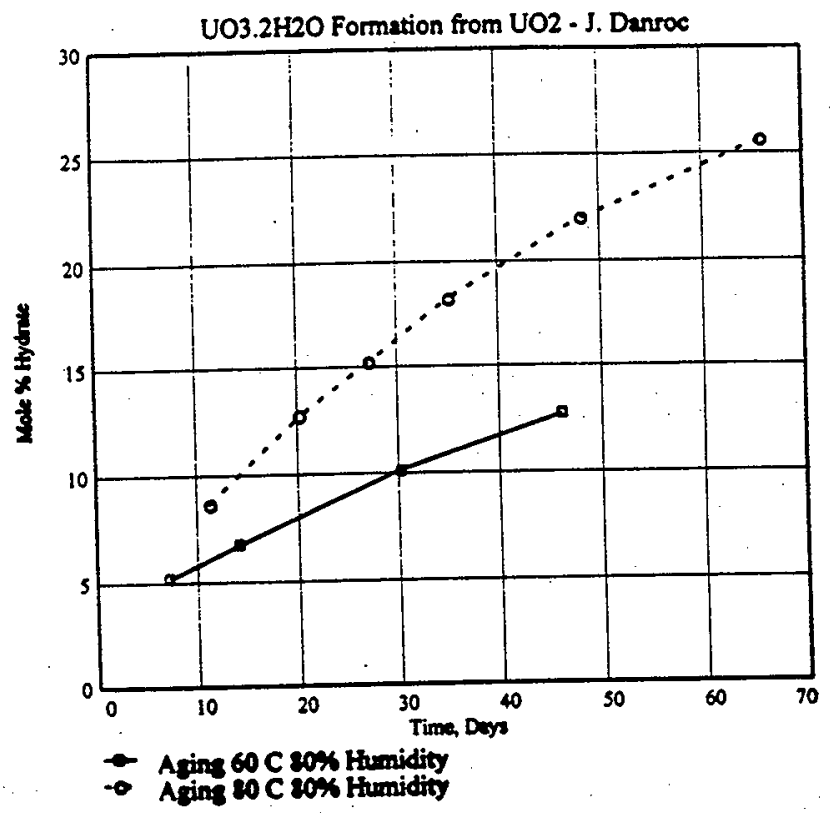


These compounds need not be considered for estimation of bounding water content because $\mathrm{UO}_{3} \cdot 2 \mathrm{H}_{2} \mathrm{O}$ has about twice the water.

\section{C.5 References}

J. Danroc, "Evolution Superficielle et Aptitude au Compactage des Poudres de Dioxyde d'Uranium," Doctoral Thesis, l'Institut National Polytechnique de Grenoble, April 1982.

H. R. Hoekstra and S. Siegel, "The Uranium Trioxide-Water System," J. Inorg. Nucl. Chem., Vol. 35, pp. 761-779, Pergamon Press, UK, 1973.

Joseph J. Katz and Eugene Rabinowitch, "The Chemistry of Uranium: The Element, Its Binary and Related Compounds," National Nuclear Energy Series, Manhattan Project Technical Section, Division VIII - Volume 5, Dover Publications, New York, 1951.

P. Taylor, R. J. LeMire, and D. W. Wood, "The Influence of Moisture on Air Oxidation of $\mathrm{UO}_{2}$ : Calculations and Observations," Nucl. Tech., Vol. 42, Nov. 1993, pp. 164-170. 


\section{APPENDIX D \\ URANIUM TRIOXIDE HYDRATE DECOMPOSITION}

\section{D.1 Purpose and Summary}

The purpose of this Appendix is to summarize literature data on the decomposition of uranium uxide hydrates, chiefly $\mathrm{UO}_{3}-2 \mathrm{H}_{2} \mathrm{O}$ and its decomposition products with $\mathrm{x}<2$, where $\mathrm{x}$ is the water stoichiometry number.

Literature data for $\mathrm{UO}_{3} \cdot \mathrm{HH}_{2} \mathrm{O}$ decomposition may be summarized as:

1. Loss of the first mole of $\mathrm{H}_{2} \mathrm{O}$ from $\mathrm{UO}_{3} \cdot 2 \mathrm{H}_{2} \mathrm{O}$ depends strongly upon the ambient water vapor pressure and is in accord with equilibrium data.

2. Loss of the first mole of $\mathrm{H}_{2} \mathrm{O}$ from $\mathrm{UO}_{3} \cdot 2 \mathrm{H}_{2} \mathrm{O}$ is expected to occur in about 100 hours at $75^{\circ} \mathrm{C}$ given a water vapor pressure low enough, presumably below $1 \mathrm{kPa}$.

3. Loss of the remaining water requires temperatures well above $100^{\circ} \mathrm{C}$ and a kinetic rate law is required to quantify the time; the ambient water vapor pressure should not matter so long as it is well below the equilibrium for decomposition.

\section{D.2 Literature Data [Hoekstra and Siegel. 1973]}

The most comprehensive study of $\mathrm{UO}_{3} \times \mathrm{xH}_{2} \mathrm{O}$ decomposition routes is probably that of [Hoekstra and Siegel, 1973]. These authors summarize previous references and conclude that $\mathrm{UO}_{3} \cdot 2 \mathrm{H}_{2} \mathrm{O}$ tends to decompose to $\mathrm{UO}_{3} \cdot 0.8 \mathrm{H}_{2} \mathrm{O}$. Unfortunately, this is not always true because the data of [Danroc, 1982] clearly show intermediate formation of $\mathrm{UO}_{3} \cdot \mathrm{H}_{2} \mathrm{O}$. Note that the hydrates are written here as $\mathrm{UO}_{3} \times \mathrm{H}_{2} \mathrm{O}$, but in references like Hoekstra and Siegel care is taken to identify the precise structures, for example $\mathrm{UO}_{2}(\mathrm{OH})_{2}$ is a more proper way to express the monohydrate. For our purposes here the actual structures require no discussion, and the impact 
of the structures is directly addressed by the choice of thermodynamic data and by the real, observed decomposition behavior that will be captured by equilibrium and kinetic models.

Danroc provides decomposition histories for four samples at $25^{\circ} \mathrm{C}$ and vacuum that can be used for the first phase of $\mathrm{UO}_{3} \cdot 2 \mathrm{H}_{2} \mathrm{O}$ decomposition. Danroc also provides histories for two heatup rates, $4^{\circ} \mathrm{C} / \mathrm{hr}$ and $5^{\circ} \mathrm{C} / \mathrm{min}$, from $25^{\circ} \mathrm{C}$ to $400^{\circ} \mathrm{C}$ that can be used for the loss of remaining water. Danroc's decomposition data are shown in Figure D-1.

The first portion of the data indicates time in hours under vacuum of $10^{-5}$ torr or about $10^{-3} \mathrm{~Pa}$ at $25^{\circ} \mathrm{C}$ for four samples treated for $0,20,35$, and 66 days in humid air at $80^{\circ} \mathrm{C}$. Note from Figure D-1 that Danroc's samples were only partially hydrated. The extent of hydration increased with treatment time (see Appendix C). Danroc believed the hydrate existed as a layer surrounding an oxide nucleus.

The second portion of the data is for temperatures above $25^{\circ} \mathrm{C}$. Here there are four pairs of curves where the dashed line corresponds to heating at a slow rate, $4^{\circ} \mathrm{C} /$ hour, and the solid line corresponds to heating at a rapid rate, $5^{\circ} \mathrm{C} /$ minute. Danroc's particle sizes were very small, about $0.2 \mu \mathrm{m}$, so the combination of very low pressure and very small particles makes it difficult to directly apply his results for $\mathrm{K}$-basins sludge.

[Katz and Rabinowitch, 1951] reference a Columbia study and provide a data table for loss of the first mole of water from $\mathrm{UO}_{3} \cdot 2 \mathrm{H}_{2} \mathrm{O}$ at four temperatures, $61^{\circ} \mathrm{C}, 77^{\circ} \mathrm{C}, 100^{\circ} \mathrm{C}$, and $118^{\circ} \mathrm{C}$ in water vapor of unknown partial pressure, and one point in vacuum at $28^{\circ} \mathrm{C}$. Columbia data were mistakenly quoted by Katz and Rabinowitch in terms of minutes, but the correct durations are in hours:

\begin{tabular}{|c|c|c|c|c|c|c|}
\hline \multicolumn{6}{|c|}{ Time Required for $\mathrm{UO}_{3} \cdot 2 \mathrm{H}_{2} \mathrm{O}$ Decomposition to $\mathrm{UO}_{3} \cdot \mathrm{H}_{2} \mathrm{O}$, hours. } \\
\hline Sample & Vacuum & $61^{\circ} \mathrm{C}$ & $77^{\circ} \mathrm{C}$ & $87^{\circ} \mathrm{C}$ & $100^{\circ} \mathrm{C}$ & $118^{\circ} \mathrm{C}$ \\
\hline From $\mathrm{UO}_{3}$ & - & $>518$ & $<95$ & $>12$ & $<2$ & $<1$ \\
From $\mathrm{UO}_{4}$ & $<123$ & $>100$ & $<122$ & $<2$ & - & - \\
\hline
\end{tabular}

FAI/98-97, Rev. 3

$\mathrm{D}-2$

Date: $10 / 21 / 98$ 
Figure D-1: French $\mathrm{UO}_{3} \times \mathrm{xH}_{2} \mathrm{O}$ Decomposition Data [Danroc, 1982].

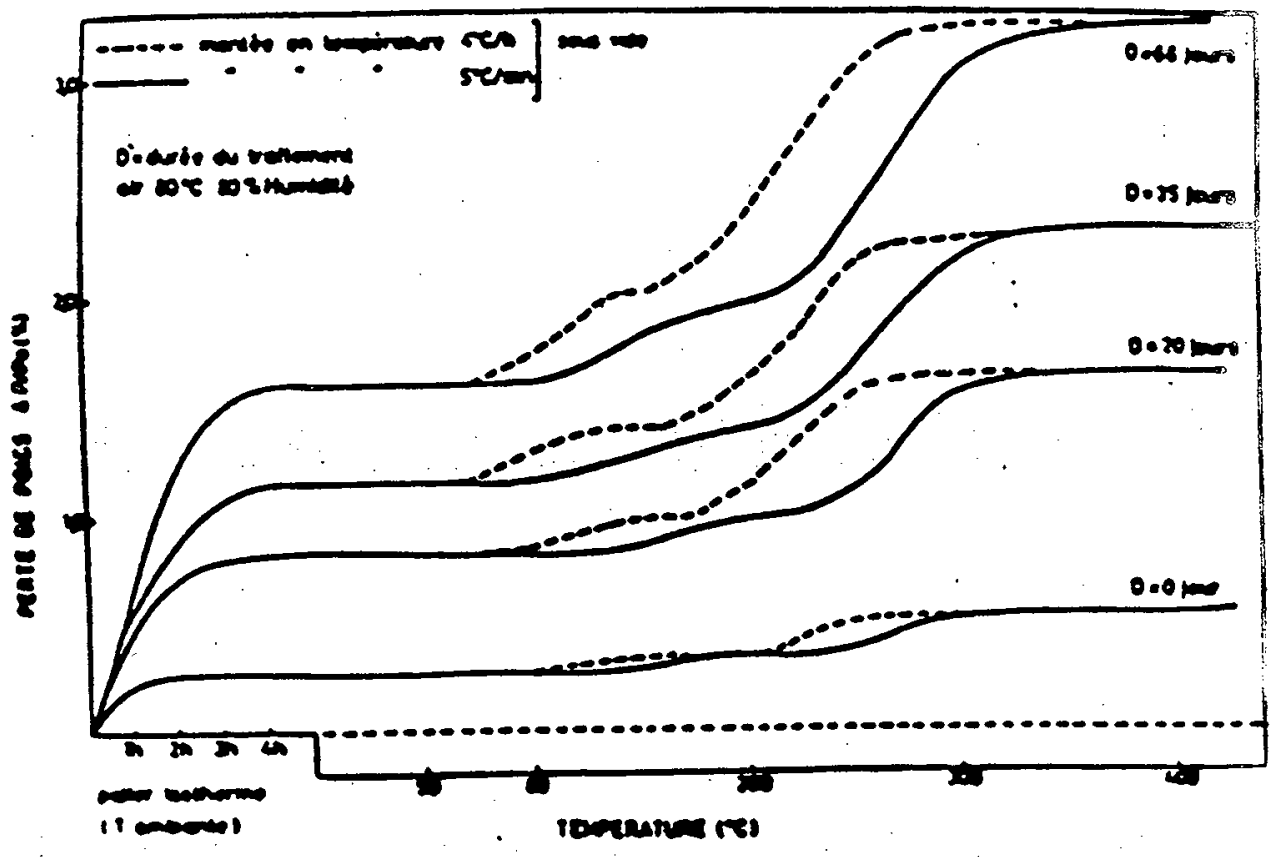


These data at $77^{\circ} \mathrm{C}$ are in accord with PNNL data for $\mathrm{K}$-basins sludge to be discussed below, wherein a half-life for decomposition at $75^{\circ} \mathrm{C}$ is about 40 hours. These data are consistent with the following interpretation: below about $100^{\circ} \mathrm{C}$, the water vapor partial pressure is very -important in determining the rate of decomposition, and above $100^{\circ} \mathrm{C}$ for water vapor pressures well below $1 \mathrm{~atm}$, this effect is not important. This interpretation follows from the observation of greater than 518 hours for decomposition at $61^{\circ} \mathrm{C}$-- whereas Danroc observed complete decomposition in less than 240 minutes at $25^{\circ} \mathrm{C}$ under vacuum; this interpretation is also expected from thermodynamic data.

[Huttig and von Schroeder, 1922], also cited in [Katz and Rabinowitch, 1951] provide a data table for loss of water under about 15 torr water partial pressure, or $2 \mathrm{kPa}$, and for temperatures up to $450^{\circ} \mathrm{C}$. Here one sample was heated and examined after various temperatures were attained, but the heating schedule is not stated, and several data points were taken at $100^{\circ} \mathrm{C}$ but the dwell time was not indicated. It is not clear why several points were taken at $100^{\circ} \mathrm{C}$ although this was probably done because the decomposition was observed (or anticipated) to be more rapid. Their data provide an illusion of congruent decomposition at that temperature which is contradicted by all other sources. Also the decomposition time at $100^{\circ} \mathrm{C}$ is at least 40 minutes (and probably on the order of an hour) if the $\mathrm{UO}_{4}$ heatup schedule in their paper applies to $\mathrm{UO}_{3}$ too, but this is in disagreement with the other data points presented by [Katz and Rabinowitch, 1951] discussed above. I conclude that the [Huttig and von Schroeder, $1922]$ reference is unreliable for the present work.

\section{D.3 References}

J. Danroc, "Evolution Superficielle et Aptitude au Compactage des Poudres de Dioxyde d'Uranium," Doctoral Thesis, l'Institut National Polytechnique de Grenoble, April 1982.

H. R. Hoekstra and S. Siegel, "The Uranium Trioxide-Water System," J. Inorg. Nucl. Chem., Vol. 35, pp. 761-779, Pergamon Press, UK, 1973.

G. F. Huttig and E. von Schroeder, "Uber die Hydrate des Urantetroxyds and Urantrioxyds," 1922. 
Joseph J. Katz and Eugene Rabinowitch, "The Chemistry of Uranium: The Element, Its Binary and Related Compounds," National Nuclear Energy Series, Manhattan Project Technical Section, Division VIII - Volume 5, Dover Publications, New York, 1951. 
HNF-1523, Rev I

APPENDIX E DELETED 


\section{APPENDIX F \\ INTERPRETATION OF PNNL DRYOUT EXPERIMENTS}

This appendix uses PNNL data for dryout K-basin canister sludge [Abrefah, et al., 1998] to derive best-fit Arrhenius parameters for decomposition. Best-fit Arrhenius parameters are found for each of three decomposition steps as described below.

Abrefah assumed a first-order Arrhenius rate law for each of three decomposition reactions:

$$
\begin{aligned}
& \frac{d w}{d t}=-K(T) w \\
& \text { ln } K=\ln k_{0}-\frac{Q}{T}
\end{aligned}
$$

where $: \mathrm{w} \quad=\quad$ weight of water for decomposition step,

$\mathrm{K}(\mathrm{T})=$ rate constant, $\mathrm{min}^{-1}$,

$\mathrm{k}_{\mathrm{o}}=$ pre-exponential factor, inverse minutes,

$\mathrm{Q}=$ activation energy, $\mathrm{K}$, and

$\mathrm{T}=$ temperature, $\mathrm{K}$.

Abrefah's fits (Table F-1) were used to create seven sets of synthetic data. A least squares fit was applied to the synthetic data to determine a best-fit.

Derived values are given in Table F-2. Figures F-1 through F-4 contain plots of Abrefah's individual experiment fits, as well as the derived best-fit.

For example, the rate constant for the first decomposition at $\mathrm{CVD}, 50^{\circ} \mathrm{C}$, is $1.316 \times 10^{-4}$ $\min ^{-1}$, which implies a decomposition half-life of 5,267 minutes or about 88 hours. 


\section{Reference:}

J. Abrefah, H. C. Buchanan, and S. C. Marschman, "Drying Behavior of K-East Canister Sludge," PNNL-11628, UC-602, Pacific Northwest National Laboratory, Richland, WA,-: May 1998.

\begin{tabular}{||c|r|r|r|r|r|r||}
\hline \multicolumn{7}{|c|}{ Table F-1: } \\
Decomposition Parameters of KE Canister Sludge \\
[Abrefah, et al., 1998] \\
\hline TGA & Pre-Exponential Factors, $\mathbf{k}_{\mathbf{0}}\left(\mathbf{m i n}^{-1}\right)$ & \multicolumn{3}{|c|}{ Activation Energies, Q (K) } \\
\cline { 2 - 7 } Run \# & Peak 1 & \multicolumn{1}{|c|}{ Peak 2 } & Peak 3 & Peak 1 & Peak 2 & Peak 3 \\
\hline 40 & 2253 & 56000 & 15600 & 5504 & 7308 & 7540 \\
41 & 16000 & 19900 & 11500 & 6010 & 6750 & 7350 \\
42 & 40000 & 59400 & 10100 & 6104 & 7300 & 7515 \\
43 & 24 & 48100 & 6700 & 3687 & 7550 & 7700 \\
44 & 324 & 28000 & 4400 & 5000 & 7200 & 7500 \\
45 & 238 & 11000 & 1400 & 4471 & 6950 & 7480 \\
46 & 326 & 56700 & 4513 & 5003 & 7630 & 7754 \\
\hline
\end{tabular}

\begin{tabular}{|c|c|c|}
\hline \multicolumn{3}{|c|}{ Table F-2: } \\
\hline \multicolumn{3}{|c|}{ Best-Fit Arrhenius Parameters for Decomposition } \\
\hline Step & $\begin{array}{c}\text { Pre-Exponential Factor, } k_{0}, \\
\text { (inverse minutes) }\end{array}$ & $\begin{array}{c}\text { Activation Energy, Q, } \\
\text { (Kelvins) }\end{array}$ \\
\hline 1 & 980 & 5111 \\
\hline 2 & 34280 & 7241 \\
\hline 3 & 6162 & 7548 \\
\hline
\end{tabular}


Figure F-1

CHECK ABREFAH'S PEAK 33 DATA - GET BEST FIT FOR TRANSIENT CALCULATIONS :-

Pre-exponential, inverse minutes

$K_{0}=\begin{array}{rr}15.6^{\circ} & 7540^{\circ} \\ 11.5 & 7350 \\ 10.1 & 7515 \\ 6.7 \cdot 10^{3} & Q=7700 \\ 4.4 & 7500 \\ 1.4 & 7480 \\ 4.51 . & .7754\end{array}$

Evaluate from $150 \mathrm{C}$ to $400 \mathrm{C}$ every $10 \mathrm{C}$

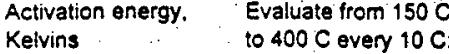

$$
\begin{aligned}
& i=0 . .25 \quad T_{i}=273-150-10 \cdot i \\
& j=0 . .6 \quad k_{i, j}=7 \cdot i-j
\end{aligned}
$$

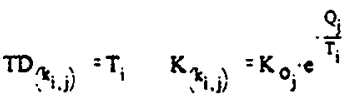

$$
\begin{aligned}
& v X_{\left.x_{i, j}\right)}=\frac{1}{T_{i}} \quad v Y_{k_{i, j}}=\ln \left[K_{x_{i, j j}} .\right.
\end{aligned}
$$

Best-fit values for 150 to $300 \mathrm{C}$ :
$A=$ intercept $(V X, V Y) \quad K_{\text {ave }}=e^{A}$
$K_{\text {ave }}=6.162 * 10^{3}$
$Q_{\text {ave }}=\cdot \operatorname{slope}(V X, V Y) \quad Q_{\text {ave }}=7.548 \cdot 10^{3}$
Evaluate best fit:
$Y_{\text {ave }}=\ln ! K_{\text {ave }} \cdot e^{-\frac{Q_{\text {ave }} !}{T_{i}}} ;$

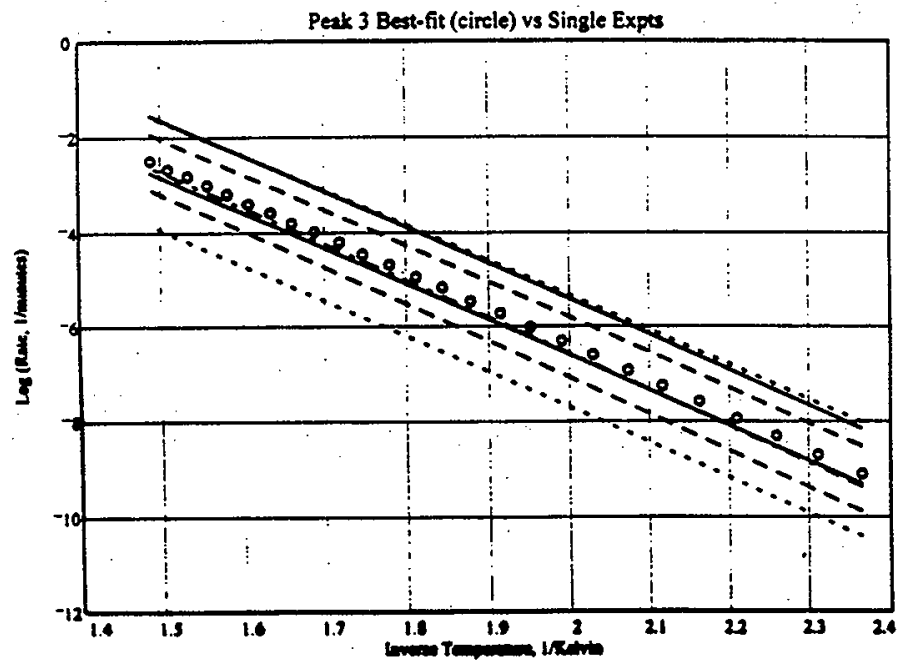




\section{Figure F-2}

CHECK ABREFAHS PEAK "2 DATA - GET BEST FIT FOR TRANSIENT CALCULATIONS ::

Pre-exponential. inverse minutes

$\begin{array}{lr}56.0^{\circ} & -7308^{\circ} \\ 19.9 & 6750 \\ 59.4 & 7300 \\ K_{0}=48.1 \cdot 10^{3} & Q=7550 \\ 28.0 & 7200 \\ 11.0 & 6950 \\ 56.7 & 7630\end{array}$

Best-fit values for 150 to $300 \mathrm{C}$ :

Kelvins
$A=$ intercept $(V X, V Y) \quad K_{\text {ave }}=e^{A}$

$Q_{\text {ave }}=\cdot \operatorname{slope}(V X, V Y) \quad Q_{\text {ave }}=7.241 \cdot 10^{3}$
Evaluate from $150 \mathrm{C}$ to $300 \mathrm{C}$ every $10 \mathrm{C}$.

$$
\begin{aligned}
& i=0.15 \quad T_{1}: 70-150-10 . i \\
& j=0.6 \quad k_{1, j}=7 \cdot i-j
\end{aligned}
$$

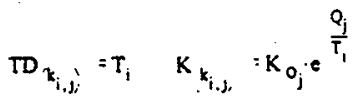

$$
\begin{aligned}
& v X_{x_{i, j},}=\frac{1}{T_{i}} \quad v Y_{k_{i, j}}=\ln i K_{x_{i, j,}} .
\end{aligned}
$$

Activation energy.

$K_{\text {ave }}=3.428 \cdot 10^{4}$

Evaluate best fit:
$Y_{\text {ave }_{i}}=\ln K_{\text {ave }} e^{\frac{Q_{\text {ave }}}{T_{1}}}$

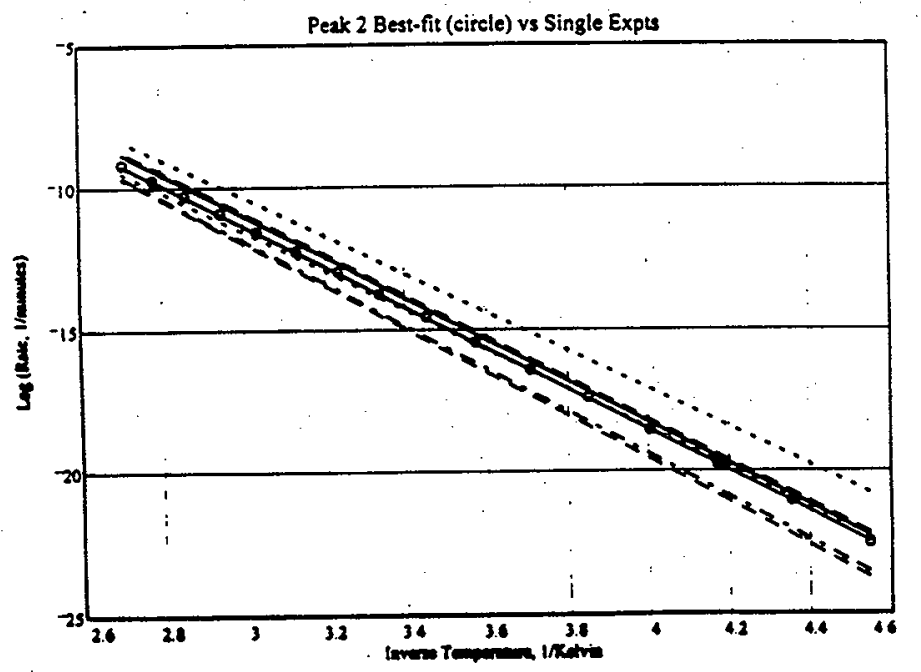




\section{Figure F-3}

\section{IHECX ABREFAH'S PEAK * I DATA - OMIT TGA * 43, 46 FOR BEST ESTIMATE}

pre-exponential.

inverse minutes
Activation energy,

Kelvins
Evaluate from $70 \mathrm{C}$

to $220 \mathrm{C}$ every $10 \mathrm{C}$ :
$i=0.15$
$T_{1}=273-70-10 \cdot i$
2253
16000
$K_{0}=40000$
324.
238.
$5504^{\circ}$
6010
$Q=6104$
5000
4471 .
$j=0 . .4$
$k_{i, j}=5 \cdot i-j$
$T D_{k_{i, j}, j}=T_{i} \quad K_{x_{i, j} j}=K_{o_{j} \cdot e} \frac{Q_{j}}{T_{i}}$
$v X_{k_{i, j} j}=\frac{1}{T_{i}} \quad v Y_{\left.k_{i, j}\right)}=\ln K_{k_{i, j},}$.

Best-fit values for 70 to $220 \mathrm{C}$ :
$A$ : intercept( $V X, V Y)$
$K_{\text {ave }}=e^{A}$
$K_{\text {ave }}=1.103 \cdot 10^{3}$
$Q_{\text {ave }}=\cdot \operatorname{slope}(V X, V Y)$
$Q_{\text {ave }}=5.104 \cdot 10^{3}$
Evaluate best fit:

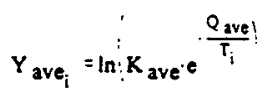

Halfolife at $75 \mathrm{C}$ should be 30 to 60 hours: $\quad K 75=K_{\text {ave }} \cdot e^{-\frac{Q_{\text {ave }}}{348.15}} \quad t_{75}=0.693 \cdot K_{75^{-1}} \cdot 60^{-1} \quad i_{75}=24.328$

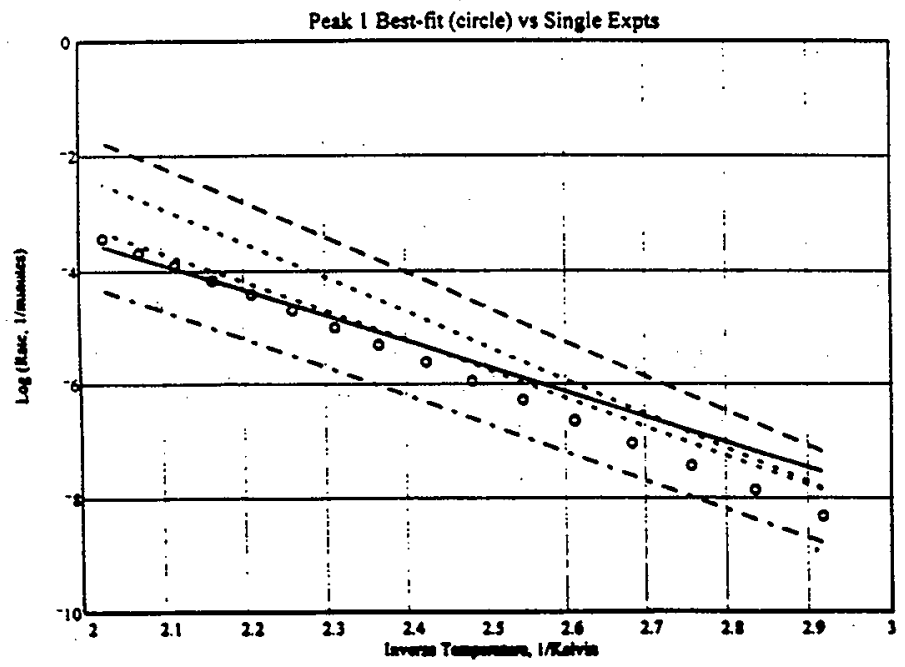


Figure F-4

CHECK ABREFAHS PEAK 11 DATA - GET BEST FIT FOR TRANSIENT CALCULATIONS

Pre-exponentia!. inverse minutes

$K_{0}=\begin{array}{cr}2253 & 5504 \\ 16000 & 6010 \\ 40000 & 6104 \\ 24.0 & Q=3687 \\ 324 . & 5000 \\ 238 . & 4471 \\ 326 . & 5003 .\end{array}$

Kelvins
Activation energy. Evaluate from $70 \mathrm{C}$

to $220 \mathrm{C}$ every $10 \mathrm{C}$ :

i $0.15 \quad T_{1}=273-70-10 . i$

$j=0.6 \quad k_{i . j}=7 \cdot i-j$

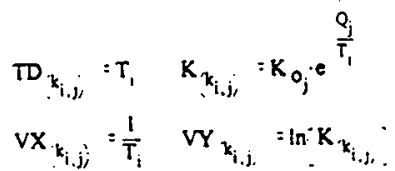

Best-fit values for 70 to $220 \mathrm{C}$ :

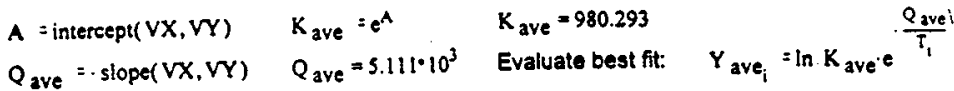
Half-life at $75 \mathrm{C}$ should be 30 to 60 hours: $\quad K 75=K_{\text {ave }} e^{\frac{Q_{\text {ave }}}{348.15}} \quad$ is $=0.693 \cdot \mathrm{K} 75^{-1} \cdot 60^{-1} \quad t 75=28.004$

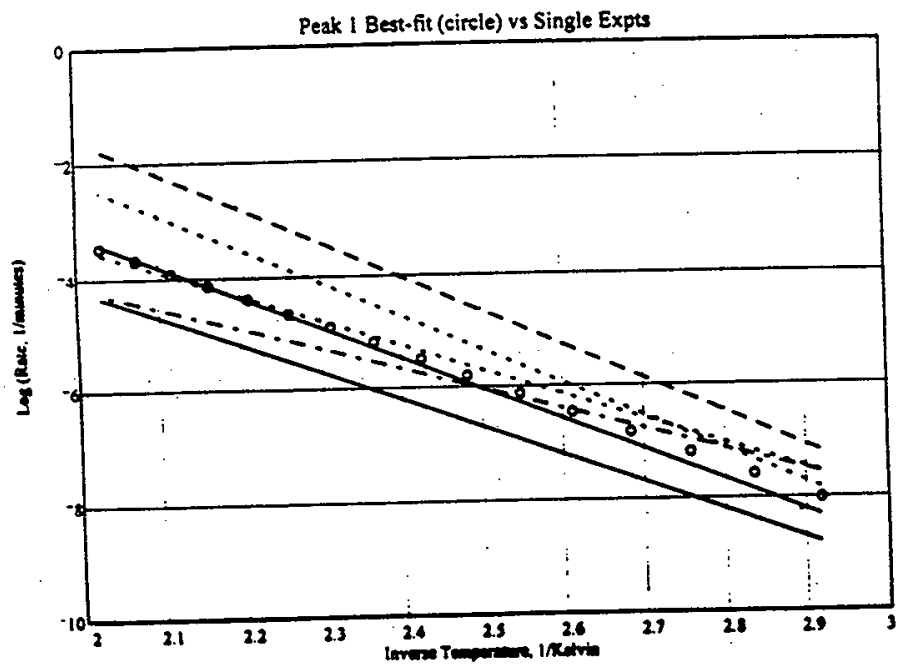




\section{APPENDIX G \\ URANIUM PEROXIDE HYDRATE FORMATION AND DECOMPOSITION}

\section{G.1 Purpose and Summary}

The purpose of this Appendix is to review literature data on formation and decomposition of uranium peroxide hydrates, $\mathrm{UO}_{4} \cdot 4 \mathrm{H}_{2} \mathrm{O}$, and $\mathrm{UO}_{4} \cdot 2 \mathrm{H}_{2} \mathrm{O}$.

Two literature sources and recent PNNL data support a conclusion that $\mathrm{UO}_{4} \cdot 4 \mathrm{H}_{2} \mathrm{O}$ will easily decompose to $\mathrm{UO}_{4} \cdot 2 \mathrm{H}_{2} \mathrm{O}$ during cold vacuum drying conditions which include a proof test at $75^{\circ} \mathrm{C}$.

\section{G.2 Formation}

$\mathrm{UO}_{4} \cdot \mathrm{xH}_{2} \mathrm{O}$ was prepared by precipitation from uranyl nitrate solution in the three references consulted here: [Huttig and von Schroeder, 1922], [Sato, 1963], and [Boggs and ElChehabi, 1957]. It is not clear whether significant quantities of $\mathrm{UO}_{4}$ hydrates can be formed under $\mathrm{K}$-basins conditions.

\section{G.3 Decomposition Literature}

The above references agree that $\mathrm{UO}_{4} \cdot 4 \mathrm{H}_{2} \mathrm{O}$ easily decomposes to $\mathrm{UO}_{4} \cdot 2 \mathrm{H}_{2} \mathrm{O}$ between $25^{\circ} \mathrm{C}$ and $100^{\circ} \mathrm{C}$. Further water loss and eventual decomposition to $\mathrm{UO}_{3}$ occurs at higher temperatures. There is an obvious water vapor pressure effect for the first stage of decomposition at low temperature, which is exactly as expected from thermodynamic data.

Sato presents a single curve for decomposition of $\mathrm{UO}_{4} \cdot 4 \mathrm{H}_{2} \mathrm{O}$ to $\mathrm{UO}_{4} \cdot 2 \mathrm{H}_{2} \mathrm{O}$ at room temperature, presumed $25^{\circ} \mathrm{C}$, and under vacuum, reproduced as Figure G-1. The half-life for 
Figure G-1: Variation of Mol. Ratio $\mathrm{H}_{2} \mathrm{O} / \mathrm{UO}_{4}$ in $\mathrm{UO}_{4} 4 \mathrm{H}_{2} \mathrm{O}$ (specimen 1) With Time of Drying in. Vacuum at Room Temperature [Sato, 1963]. $=$

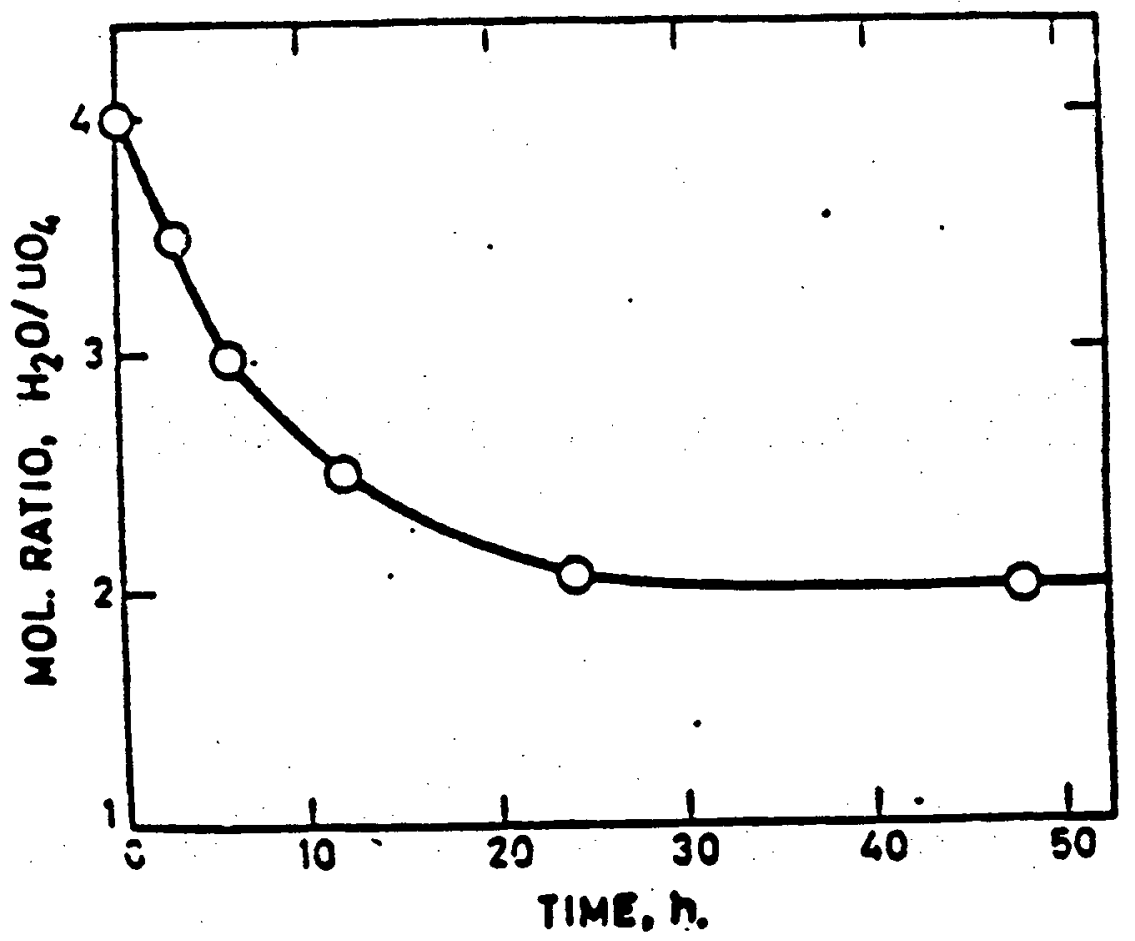


decomposition is about 6 hours and completion occurs at 24 hours. Sato also presents 17 curves for decomposition of $\mathrm{UO}_{4}$ hydrates with $\mathrm{x}=2$ to $\mathrm{x}=4 \mathrm{H}_{2} \mathrm{O}$, where the temperature was raised at $4^{\circ} \mathrm{C} /$ minute apparently in vacuum. For samples with $x>2.2$, clear breaks are apparent $=$ : between the decomposition stages. Very high temperatures, $600^{\circ} \mathrm{C}$ and above, were required for final dryout and may be attributable to either the relatively quick heatup rate or the presence of surface adsorbed water on precipitated samples of high surface area.

Boggs and El-Chehabi present rate data for $\mathrm{UO}_{4} \cdot 2 \mathrm{H}_{2} \mathrm{O}$ decomposition for various temperatures sufficient to formulate a first-order kinetic rate law between $90^{\circ} \mathrm{C}$ and $150^{\circ} \mathrm{C}$. Results in oxygen and air atmospheres were stated to be the same, as were results under 30 torr and 8 torr water vapor partial pressure (about $4 \mathrm{kPa}$ and $1 \mathrm{kPa}$, respectively). Rate law data of Boggs and El-Chehabi are summarized here:

\begin{tabular}{|c|c|c|c|c|}
\hline $\mathrm{T},{ }^{\circ} \mathrm{C}$ & 100 & 120 & 130 & 150 \\
\hline $\mathrm{k}, \mathrm{hr}^{-1}$ & $4.4 \times 10^{-4}$ & $4.0 \times 10^{-3}$ & $1.4 \times 10^{-2}$ & $1.3 \times 10^{-1}$ \\
\hline
\end{tabular}

Boggs and El-Chehabi are careful to point out "striking disagreement" between their results and those of [Huttig and von Schroeder, 1922]. [Boggs and El-Chehabi, 1957]'s rate constant at $150^{\circ} \mathrm{C}$ is $0.131 / \mathrm{hr}$, so the half-life is 5.3 hours for decomposition, while Huttig and von Schroeder report a rather steep loss of 1.5 moles $\mathrm{H}_{2} \mathrm{O}$ at 162 and $163^{\circ} \mathrm{C}$. It is worth noting here that Huttig and von Schroeder's work could be interpreted to show this decomposition occurring in about 5 hours. It is perhaps the choice of dwell time at that temperature, which creates the illusion of a congruent decomposition, that led to Boggs and El-Chehabi's objection to the Huttig and von Schroeder data.

Huttig and von Schroeder provide a data table for loss of water from $\mathrm{UO}_{4} \cdot 4 \mathrm{H}_{2} \mathrm{O}$ under about $14-17$ torr water partial pressure, about $2 \mathrm{kPa}$, and for temperatures up to $450^{\circ} \mathrm{C}$. From Figure G-2, loss of the first two moles of $\mathrm{H}_{2} \mathrm{O}$ begins at about $50^{\circ} \mathrm{C}$. Here one sample was heated and examined after various temperatures were attained, but the heating schedule is not precisely stated, and several data points were taken at 162 and $163^{\circ} \mathrm{C}$, but the dwell time was 

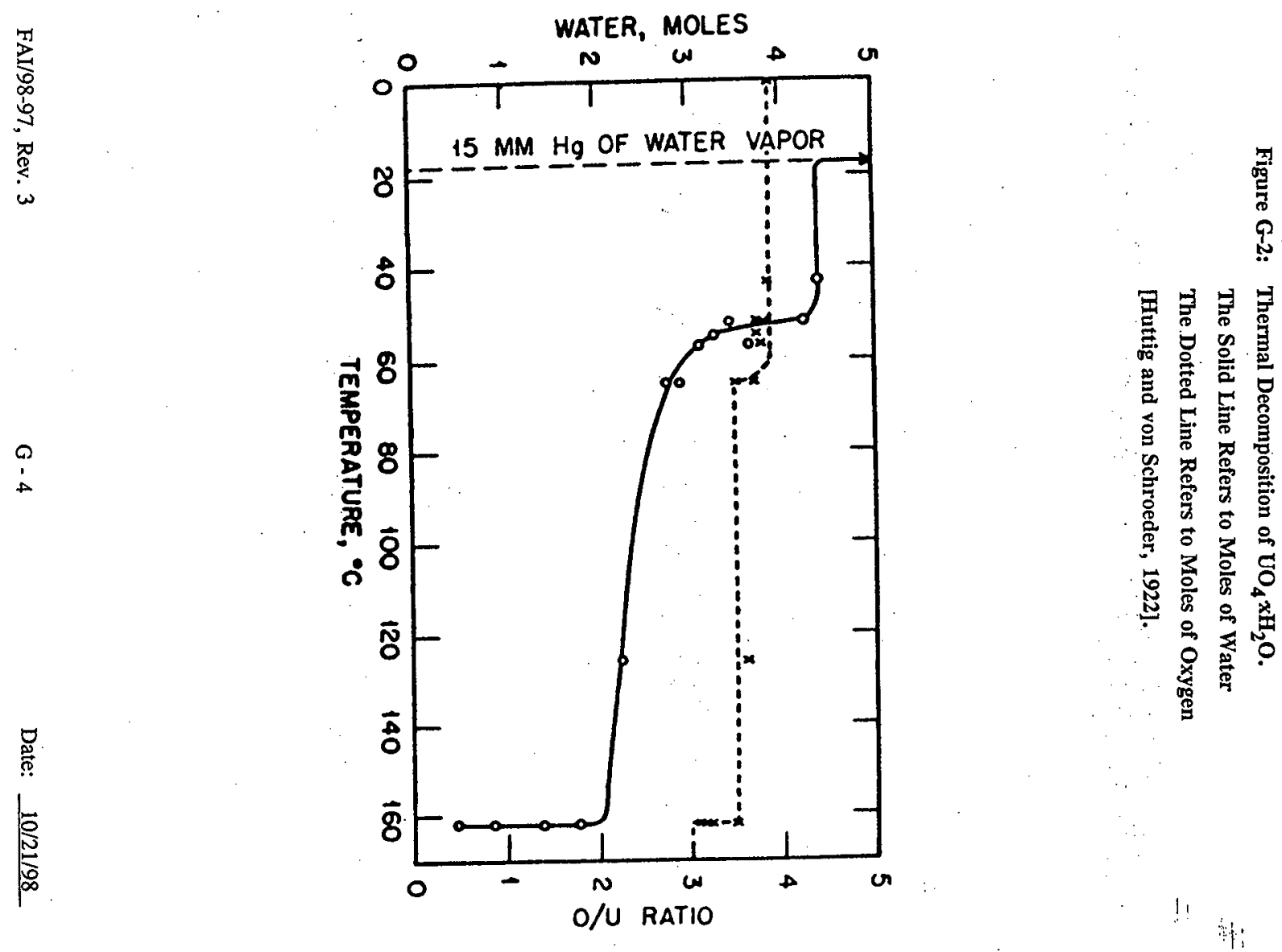
not indicated. It is not clear why several points were taken at about $162^{\circ} \mathrm{C}$ although this was probably done because the decomposition was observed (or anticipated) to be more rapid. Their data provide an illusion of congruent decomposition at that temperature which was apparently $=$ : disliked by Boggs and El-Chehabi as discussed above. The actual statement about heating rate was that measurements were taken after intervals of about 10 to 50 minutes, so it is difficult to use these data for kinetic rate laws.

\section{G.4 Recent PNNL Data}

Recent data taken by Abrefah at PNNL have been supplied in draft, unqualified form for this Appendix. X-ray diffraction data showed the composition of the grey surface coating on $\mathrm{K}$-basin fuel cladding to be $\mathrm{UO}_{4} \cdot 4 \mathrm{H}_{2} \mathrm{O}$, and complete dryout of two samples yielded a mass loss of $23 \%$, consistent with the coating being entirely composed of this hydrate.

Dryout data taken at a pressure of 5 mtorr and following the time-temperature history used for K-East canister sludge (see Appendix E) are given in Figure G-3. Decomposition of $\mathrm{UO}_{4} \cdot 2 \mathrm{H}_{2} \mathrm{O}$ appears to occur as the temperature is raised from $50^{\circ} \mathrm{C}$ to $75^{\circ} \mathrm{C}$, and reaches completion in only several hours at $75^{\circ} \mathrm{C}$. Final decomposition occurs when the sample is heated above $75^{\circ} \mathrm{C}$.

These data are in very good agreement with literature references for $\mathrm{UO}_{4} \cdot 4 \mathrm{H}_{2} \mathrm{O}$ decomposition.

\section{G.5 References}

J. E. Boggs and M. El-Chehabi, "The Thermal Decomposition of Uranium Peroxide, $\mathrm{UO}_{4}-2 \mathrm{H}_{2} \mathrm{O}, "$ J. Am. Chem. Soc., Vol. 79, p. 4258, 1957.

G. F. Huttig and E. von Schroeder, "Uber die Hydrate des Urantetroxyds and Urantrioxyds," 1922. 
Figure G-3: Draft, Unqualified PNNL Drying Curve for Surface Coating Believed Composed of $\mathrm{UO}_{4} \cdot 4 \mathrm{H}_{2} \mathrm{O}$.

Drgine of SNR Ekment 2350R Surface Coutias

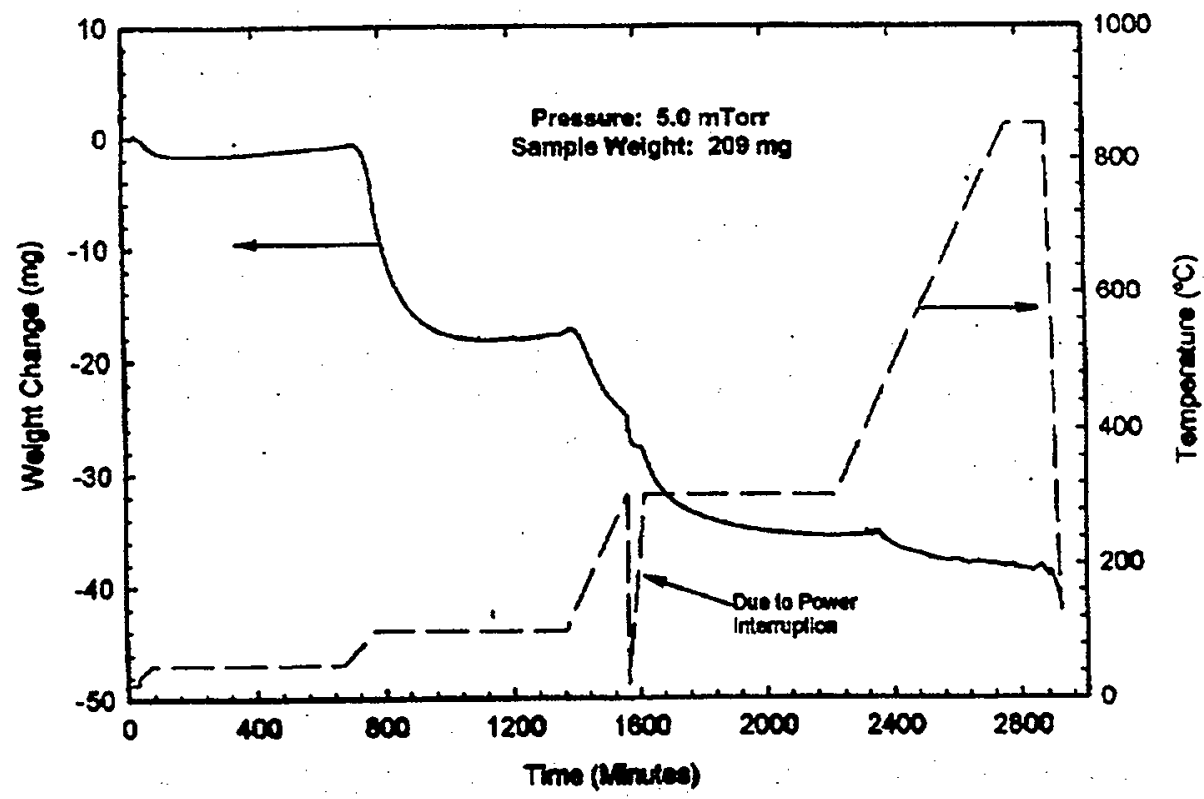


T. Sato, "Preparation of Uranium Peroxide Hydrates," J. Appl. Chem., Vol. 13, August 1963, pp. 361-365. 


\section{APPENDIX H \\ ADSORBED WATER ON OXIDE SURFACES}

\section{H.1 Purpose and Summary}

The purpose of this calculation is to quantify a possible range for adsorbed water inventory associated with exposed fuel surfaces. Considering all fuel assembly surfaces and four adsorbed layers, the adsorbed water mass is 0.1 gram. For a sensitivity case of $50 \mathrm{~kg}$ of particles with a specific area of $1.2 * 10^{6} \mathrm{~cm}^{2} / \mathrm{kg}$, the adsorbed water mass is still less than 10 grams.

\section{H.2 Calculation}

The adsorbed water mass is given by:

$$
M=\frac{n M L A}{N_{A}}
$$

where: $\mathrm{n}=$ Number density of absorption sites, $\mathrm{cm}^{-2}$,

$\mathrm{N}_{\mathrm{A}}=$ Avogadro's number, $6.023 \times 10^{23}$ per mole,

$\mathrm{M}=$ Molecular weight of water, $18 \mathrm{~g} / \mathrm{mole}$,

$\mathrm{L}=$ Number of layers, and

$A=$ Surface area, $\mathrm{cm}^{2}$.

Using a lattice parameter of about 5 angstroms [Katz, Seaborg, and Morss, 1986] and allowing one adsorption site per oxygen atom, i.e., two sites per lattice, yields a site number density of $8 * 10^{14}$ sites $/ \mathrm{cm}^{2}$, or a rounded value of $10^{15}$ sites $/ \mathrm{cm}^{2}$. Because uranium oxide hydrates could be present on cladding surfaces, the total damaged plus undamaged area of $3,156 \mathrm{~cm}^{2} /$ assembly is used for $5 * 54=270$ assemblies $/ \mathrm{MCO}$, yielding $A=850,000 \mathrm{~cm}^{2}$. For a single absorbed layer, the associated water mass is 


$$
\frac{10^{15} \frac{\text { sites }}{\mathrm{cm}^{2}} \times 18 \mathrm{~g} / \text { mole } \times 850,000 \mathrm{~cm}^{2}}{6.02 \times 10^{23} \frac{\text { sites }}{\text { mole }}}=0.025 \mathrm{~g}
$$

So even if there were 4 layers of adsorbed molecules, the water mass would only be about 0.1 gram.

Particulate can have much higher surface area, as can oxide layers with cracks. The area of particulate can be estimated by:

$$
A=\frac{6 M_{p}(1-\phi)}{\rho D}
$$

where: $\mathrm{M}_{\mathrm{p}}=$ Particulate mass, $\mathrm{g}$,

$$
\begin{aligned}
& \rho=\text { Particulate density, } \mathrm{g} / \mathrm{cm}^{3}, \\
& \phi=\text { Void fraction, and } \\
& D=\text { Particle size, } \mathrm{cm} .
\end{aligned}
$$

Taking a particle size of 3 microns, equivalent to the average layer thickness used by [Sloughter, 1998], and a void fraction of 0.4 typical of randomly packed particles, the area per kilogram of particulate is:

$$
\frac{A}{M_{p}}=\frac{6(1-0.4)\left(10^{3} \mathrm{~g} / \mathrm{kg}\right)}{\left(10 \mathrm{~g} / \mathrm{cm}^{3}\right)\left(3 \times 10^{-4} \mathrm{~cm}\right)}=1.2 \times 10^{6} \mathrm{~cm}^{2} / \mathrm{kg}
$$

It is clearly not reasonable to assign such a large specific area to all the particulate in an $\mathrm{MCO}$, since much of this value consists of oxide layers. However, assuming $50 \mathrm{~kg}$ of particulate with this surface area yields an adsorption surface area of $6 * 10^{7} \mathrm{~cm}^{2}$ and an adsorbed water mass for a single layer of $1.8 \mathrm{gram}$. Hence, multiple adsorbed layers on finely divided particles would still contribute less than 10 grams to an MCO water inventory. 


\section{H.3 References}

J. J. Katz, G. T. Seaborg, and L. R. Morss, "The Chemistry of the Actinide Elements," Second =: Edition, Chapman and Hall, New York, 1986.

J.P. Sloughter, "Estimates of Particulate Mass in Multi-Canister Overpacks," HNF-1527, Rev. 2, Numatec Hanford Corporation, Richland, WA, October 1998. 


\section{APPENDIX I \\ K-BASINS SLUDGE PHYSICAL PROPERTY DATA \\ DRAFT REFERENCE EXCERPTS}

\section{r.1 Purpose and Summary}

The purpose of this section is to describe the available sludge property data. Bulk density and particle density are of most interest. Values for $\mathrm{K}$-East sludge physical properties have been compiled and are presented here as graphs that illustrate important trends. Particle densities based on five samples show a range from 3.49 to $7.88 \mathrm{~g} / \mathrm{cc}$. The K-East maximum value for bulk density is $2.99 \mathrm{~g} / \mathrm{cc}$. Data for $\mathrm{K}$-West sludge area sparse. Only three bulk density values have been reported: $4.18 \mathrm{~g} / \mathrm{ml}, 1.66 \mathrm{~g} / \mathrm{ml}$, and $2.49 \mathrm{~g} / \mathrm{ml}$. Particles that cling tenaciously have bulk densities exceeding $4 \mathrm{~g} / \mathrm{cc}$, implying particle densities of at least $8 \mathrm{~g} / \mathrm{cc}$.

\section{I.2 K-Basins Sludge Physical Property Data}

K-East basin canister sludge physical property data have been gathered by a number of investigators and compiled by [Makenas, et al., 1997]. Data for the sludge settled bulk density (literal mass divided by volume for a wet sample), water mass and volume fractions (of wet samples), uranium mass and volume fractions (of wet samples), and particle density (the density of dried solids) data are summarized in Figure I-1. The normalized uranium mass fraction used in the figure is the mass fraction within the particles, i.e., the bulk uranium mass fraction divided by one minus the water mass fraction. The following trends are observed:

1. The water mass fraction and bulk density are correlated, as expected, and the lowest observed water mass fraction is $22 \%$.

2. Particle densities have only been measured for five samples, and range from $3.49 \mathrm{~g} / \mathrm{cc}$ to $7.88 \mathrm{~g} / \mathrm{cc}$. 
Figure I-1: K-East Sludge Observed Physical Properties.
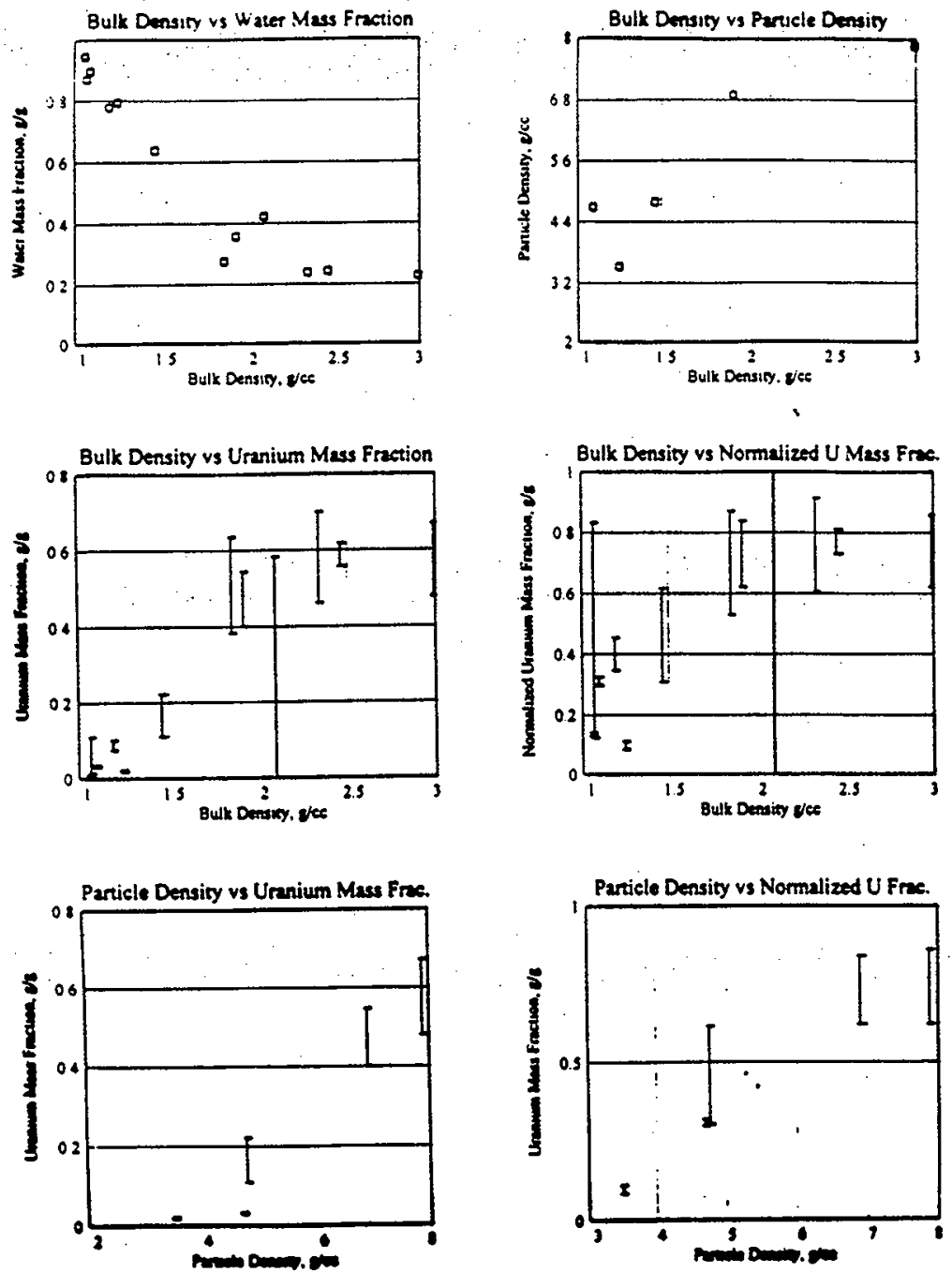
3. Bulk density and particle density are strongly correlated, as physically expected.

4. There is scatter in uranium mass fraction data, and some samples exhibited little uranium.

5. Particle density and bulk density are both correlated with uranium mass fraction and normalized uranium mass fraction. Little uranium is seen in particles with the lowest densities.

6. The normalized uranium mass fraction values are (with the exception of a sample with considerable scatter) below the mass fraction of $\mathrm{U}$ in $\mathrm{UO}_{2}$, $88 \%$. For low bulk densities, these normalized fractions are below the mass fraction of $\mathrm{U}$ in $\mathrm{UO}_{3} \cdot 2 \mathrm{H}_{2} \mathrm{O}, 74 \%$.

Data from $\mathrm{K}$-West sludge is sparse at this time. Three settled bulk densities are reported by [Makenas, Baker, and Chastain, 1997]: $4.18 \mathrm{~g} / \mathrm{ml}, 1.66 \mathrm{~g} / \mathrm{ml}$, and $2.49 \mathrm{~g} / \mathrm{ml}$. One of these values is greater than the K-East maximum value, $2.99 \mathrm{~g} / \mathrm{ml}$.

Particulate that clings tenaciously to fuel surfaces appears to have even higher density. Using measured weights and estimated volumes from [Pitner, 1997], Thierry Flament of NUMATEC calculated the bulk densities of samples removed from fuel during subsurface examination as follows:

\begin{tabular}{|c|c|l|c|c|c|}
\hline \hline Element & ID & Description & $\begin{array}{c}\text { Volume } \\
(\mathrm{ml})\end{array}$ & $\begin{array}{c}\text { Weight } \\
(\mathrm{g})\end{array}$ & $\begin{array}{c}\text { Density } \\
\left(\mathrm{g} / \mathbf{c m}^{3}\right)\end{array}$ \\
\hline \multirow{2}{*}{$6743 \mathrm{U}$} & SSL4 & Fuel Particulate from Center Breach & 1 & 4.42 & 4.42 \\
\cline { 2 - 6 } & SSL5 & Fuel Particulate from Bottom Breach & $<1$ & 1.68 & $>1.68$ \\
\hline 5427E & SSL1 & Fuel Particulate from Top End & 3 & 15.53 & 5.17 \\
\hline 7913U & SSL8 & Fuel Particulate from Center Breach & 2 & 8.19 & 4.09 \\
\hline
\end{tabular}

In all but one case, bulk densities exceeded $4 \mathrm{~g} / \mathrm{cc}$, implying the highest particle densities. Figure I-1 suggests, for example, that the particle density would be at least $8 \mathrm{~g} / \mathrm{cc}$. 
For the case of canister particulate adhering to undamaged or damaged fuel element surfaces, the bounding water content of interest is associated with low density canister material with a high proportion of $\mathrm{Al}(\mathrm{OH})_{3}$ and $\mathrm{Fe}(\mathrm{OH})_{3}$. Data from [Makenas, et al., 1997] were reviewed by [Sloughter and Barney, 1998] specifically to identify such compounds. K-East sample data exhibiting the highest possible water content may be summarized as follows:

\begin{tabular}{|c|c|c|c|c|c|c|c|c|}
\hline \multirow[b]{3}{*}{ Parameter } & \multicolumn{8}{|c|}{ Sample } \\
\hline & \multicolumn{2}{|c|}{ 96-08 } & \multicolumn{2}{|c|}{$96-09$} & \multicolumn{2}{|c|}{$96-11 U$} & \multicolumn{2}{|c|}{$96-11 \mathrm{~L}$} \\
\hline & $\begin{array}{c}\mu \mathrm{g} / \mathrm{g} \\
\mathrm{dry}\end{array}$ & $\begin{array}{l}\% \text { total } \\
\text { as } \\
\text { hydrox- } \\
\text { ide }\end{array}$ & $\begin{array}{c}\mu \mathrm{g} / \mathrm{g} \\
\mathrm{dry}\end{array}$ & $\begin{array}{l}\% \text { total } \\
\text { as } \\
\text { hydrox- } \\
\text { ide }\end{array}$ & $\underset{\mathrm{dry}}{\mu \mathrm{g} / \mathrm{g}}$ & $\begin{array}{l}\% \text { total } \\
\text { as } \\
\text { hydrox- } \\
\text { ide }\end{array}$ & $\begin{array}{c}\mu \mathrm{g} / \mathrm{g} \\
\mathrm{dry}\end{array}$ & $\begin{array}{l}\% \text { total } \\
\text { as } \\
\text { hydrox- } \\
\text { ide }\end{array}$ \\
\hline$A \ell$ & 78600 & 22.72 & 139000 & 40.18 & 139000 & 40.18 & 65500 & 18.93 \\
\hline $\mathrm{Fe}$ & 72700 & 13.91 & 210000 & 40.18 & 121000 & 23.15 & 256000 & 48.98 \\
\hline $\mathrm{U}$ & 385000 & 49.50 & 131000 & 16.84 & 133000 & 17.10 & 77900 & 10.02 \\
\hline Total (1) & - & 88.2 & - & 100.51 & - & 86.43 & - & 80.43 \\
\hline Water \% (2) & & $17 \%$ & & $26 \%$ & & $21.6 \%$ & & $20 \%$ \\
\hline U wt. \% (3) & & 40 & & 8.8 & & - & & 9.3 \\
\hline Density, $\mathrm{g} / \mathrm{ml}$ & & 1.53 & & 1.2 & & 1.27 & & 1.4 \\
\hline
\end{tabular}

The above selected data represent $\mathrm{K}$-East canister sludge samples with the highest water content and with uranium content below $40 \%$. Available K-West data exhibit uniformly lower water content by about a factor of two (see Figure 3-1). [Sloughter and Barney, 1998] note that typical $\mathrm{A} \ell: \mathrm{Fe}$ ratios in canister sludge are $1: 1$, while typically the $U$ content is $75 \%$. Also, the average K-East bulk sludge density is about $1.62 \mathrm{~g} / \mathrm{cm}^{3}$ while that of $\mathrm{K}$-West is $2.68 \mathrm{~g} / \mathrm{cm}^{3}$ [Sloughter, 1998]. Clearly, the $\mathrm{U}$ content is much lower and particles are of low density when the water content is high.

Other pertinent physical property data are the densities of pure materials: 


$\begin{array}{ll}\mathrm{UO}_{2} & 10.95 \mathrm{~g} / \mathrm{cc} \\ \mathrm{U}_{4} \mathrm{O}_{9} & \approx 11 \\ \mathrm{U}_{3} \mathrm{O}_{7} & 11.32 \\ \mathrm{UO}_{3} \cdot 2 \mathrm{H}_{2} \mathrm{O} & 4.83 \text { to } 5.0 \\ \mathrm{U} & 19.05 \\ \mathrm{UO}_{4} \cdot 2 \mathrm{H}_{2} \mathrm{O} & 4.66 \\ \mathrm{UO}_{4} \cdot 4 \mathrm{H}_{2} \mathrm{O} & 5.15\end{array}$

\section{I.3 References}

B.J. Makenas, et al., "Analysis of Sludge from Hanford K East Basin Canisters," HNF-SP1201, UC-2070, September 1997.

B.J. Makenas, R.B. Baker, and S.A. Chastain, "Highlight Report: Gas Generation, Density, and Particle Size of K West Basin Canister Sludge," DESH-9757167, 1997.

A.L. Pitner, "K-Basin Fuel Subsurface Examinations and Surface Coating Sampling," HNF-SDSNF-TI-060, Rev. 0, DE\&S Hanford, Richland, WA, September 1997.

J.P. Sloughter, "Estimates of Particulate Mass in Multi-Canister Overpacks, " HNF-1527, Rev. 2, Numatec Hanford Corporation, Richland, WA, October 1998.

Sloughter, J.P., and Barney, G.S., "Identities of Compounds in Spent Nuclear Fuel Coatings and Particulates Sealed in Multi-Canister Overpacks," HNF-2667, Rev. 1 (Draft), Numatec Hanford Corporation, Richland, WA, July 1998. 


\section{APPENDIX J}

\section{DELETED}


HNF-1523, Rev 1

APPENDIX K DELETED 


\section{APPENDIX L}

CALCULATION NOTE COVER SHEET AND METHODOLOGY CHECKLIST 


\section{CALCULATION NOTE COVER SHEET}

SECTION TO BE COMPLETED BY AUTHOR(S):

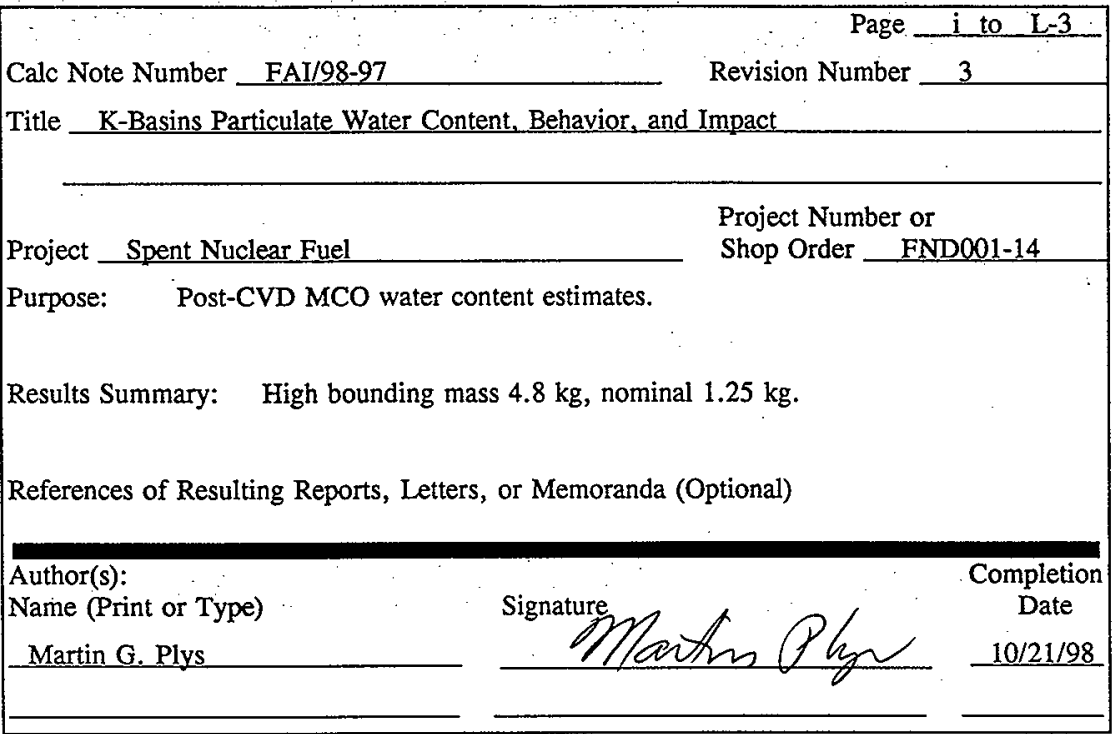

SECTION TO BE COMPLETED BY VERIFIER(S):

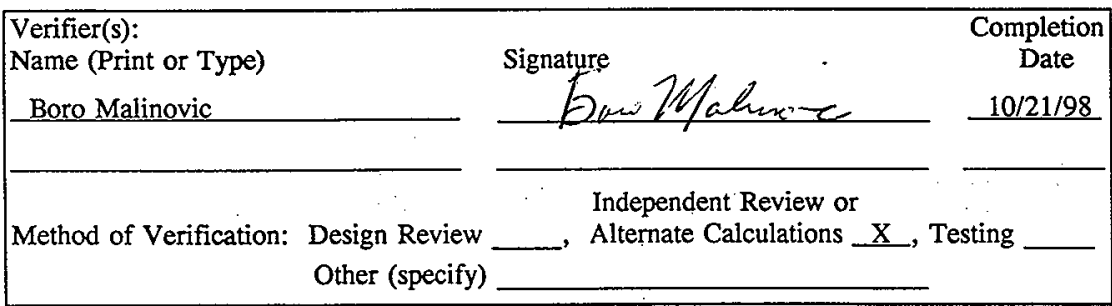

\section{SECTION TO BE COMPLETED BY MANAGER:}

Responsible Manager:

Name (Print or Type)

Martin G. Plys

Signatyeg/2 \begin{tabular}{c} 
Approval \\
Date \\
$10 / 21 / 98$ \\
\hline
\end{tabular}




\section{CALCULATION NOTE METHODOLOGY CHECKLIST}

\section{CHECKLIST TO BE COMPLETED BY AUTHOR(S) (CIRCLE APPROPRIATE RESPONSE)}

1. Is the subject and/or the purpose of the design analysis clearly stated? ..... ES. No

2. Are the required inputs and their sources provided? ...........ES . No . N/A

3. Are the assumptions clearly identified and justified? ... . . . . . . No . N/A

4. Are the methods and units clearly identified? $\ldots \ldots \ldots \ldots \ldots \ldots$ YES . NO . N/A

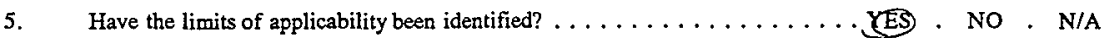
(i.e., Is the analysis for a 3 or 4 loop plant or for a single application.)

6. Are the results of literature searches, if conducted, or other background

data provided? ..................... No . N

7. Are all the pages sequentially numbered and identified by the calculation note number? $\ldots \ldots \ldots \ldots \ldots \ldots \ldots \ldots \ldots \ldots \ldots \ldots \ldots$ Y $\ldots \ldots \ldots$

8. Is the project or shop order clearly identified? ........... IES . NO

9. Has the required computer calculation information been provided? . . . ES . NO N/A

10. Were the computer codes used under configuration control? . . . . . Y YES NO . NT

11. Was the computer code(s) used applicable for modeling the physical and/or computational problems identified? ............... NES NO . N (i.e., Is the correct computer code being used for the intended purpose.)

12. Are the results and conclusions clearly stated? ............. NO

13. Are Open Items properly identified? ............... YES . No . NA

14. Were approved Design Control practices followed without exception? . . . . YES . NO . N/A (Approved Design Control practices refers to guidance documents within NSD that state how the work is to be performed, such as how to perform a LOCA analysis.)

15. Have all related contract requirements been met? .......... . NO . N/A

NOTE: If NO to any of the above, Page Number containing justification 


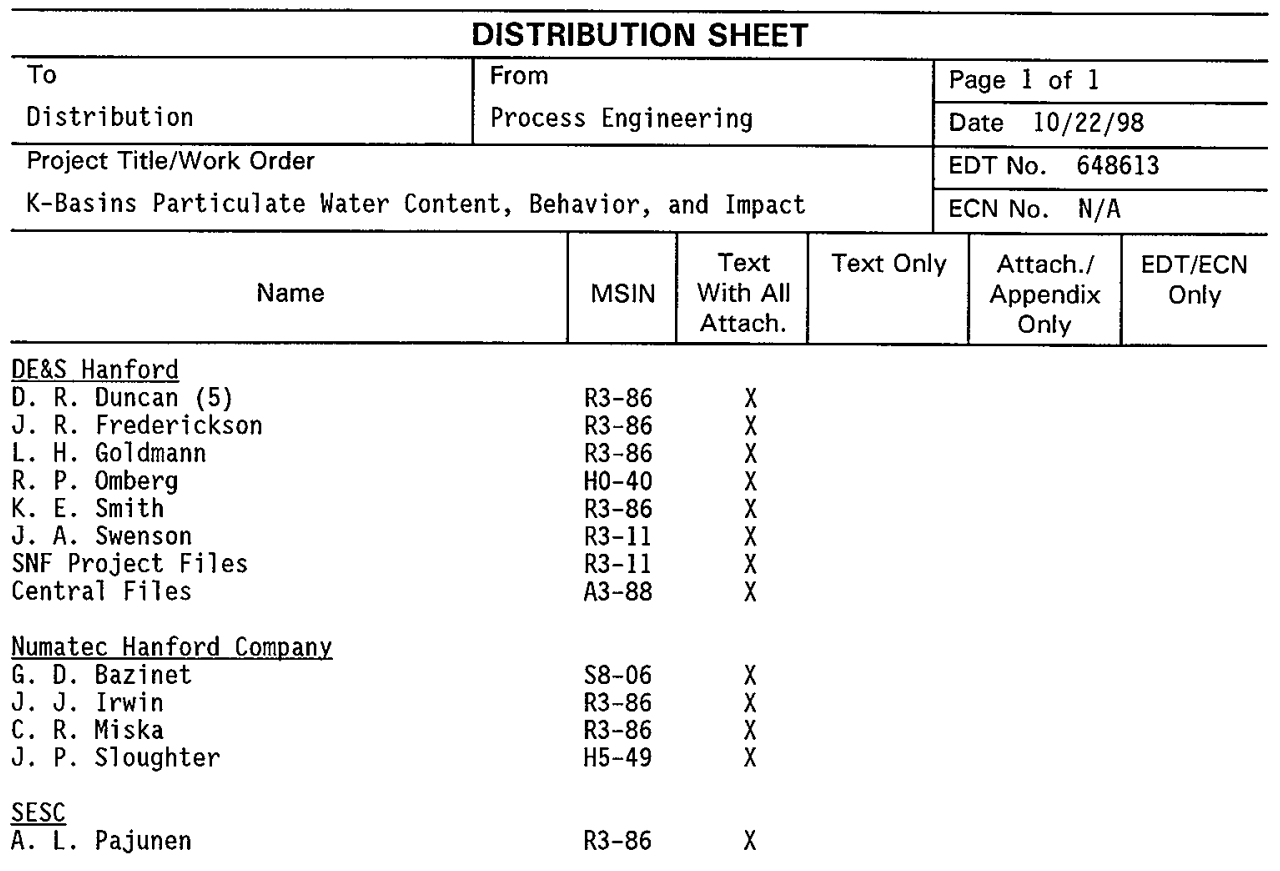

